\title{
The Host Cell ViroCheckpoint: Identification and Pharmacologic Targeting of Novel Mechanistic Determinants of Coronavirus-Mediated Hijacked Cell States
} \author{
Sergey Pampou ${ }^{2}$, Andrea Califano ${ }^{2,3,4,5,6, \bigotimes}$, and Mariano J. Alvarez ${ }^{1,2, \mathbb{}}$ \\ ${ }^{1}$ DarwinHealth Inc, New York, NY, USA. \\ ${ }^{2}$ Department of Systems Biology, Columbia University Irving Medical Center, New York, NY, USA. \\ ${ }^{3}$ Herbert Irving Comprehensive Cancer Center, Columbia University Irving Medical Center, New York, NY, USA \\ ${ }^{4}$ Department of Medicine, Columbia University Irving Medical Center, New York, NY, USA. \\ ${ }^{5}$ Department of Biochemistry \& Molecular Biophysics, Columbia University Irving Medical Center, New York, NY, USA \\ ${ }^{6}$ Department of Biomedical Informatics, Columbia University Irving Medical Center, New York, NY, USA.
}

Pasquale Laise $^{1,2}$, Gideon Bosker ${ }^{1}$, Xiaoyun Sun ${ }^{1}$, Yao Shen ${ }^{1}$, Eugene F. Douglass ${ }^{2}$, Charles Karan ${ }^{2}$, Ronald B. Realubit ${ }^{2}$,

\begin{abstract}
Most antiviral agents are designed to target virus-specific proteins and mechanisms rather than the host cell proteins that are critically dysregulated following virus-mediated reprogramming of the host cell transcriptional state. To overcome these limitations, we propose that elucidation and pharmacologic targeting of host cell Master Regulator proteins-whose aberrant activities govern the reprogramed state of coronavirusinfected cells-presents unique opportunities to develop novel mechanism-based therapeutic approaches to antiviral therapy, either as monotherapy or as a complement to established treatments. Specifically, we propose that a small module of host cell Master Regulator proteins (ViroCheckpoint) is hijacked by the virus to support its efficient replication and release. Conventional methodologies are not well suited to elucidate these potentially targetable proteins. By using the VIPER network-based algorithm, we successfully interrogated $12 \mathrm{~h}, 24 \mathrm{~h}$, and $48 \mathrm{~h}$ signatures from Calu-3 lung adenocarcinoma cells infected with SARS-CoV, to elucidate the time-dependent reprogramming of host cells and associated Master Regulator proteins. We used the NYS CLIA-certified Darwin OncoTreat algorithm, with an existing database of RNASeq profiles following cell perturbation with 133 FDA-approved and 195 late-stage experimental compounds, to identify drugs capable of virtually abrogating the virus-induced Master Regulator signature. This approach to drug prioritization and repurposing can be trivially extended to other viral pathogens, including SARS-CoV-2, as soon as the relevant infection signature becomes available.
\end{abstract}

Coronavirus | Regulatory networks | Master regulator | Anti-viral drugs

Correspondence: acc2248@cumc.columbia.edu malvarez@darwinhealth.com

\section{Introduction}

SARS-CoV is an enveloped, positive-sense, single-stranded RNA virus of the genera Betacoronavirus introduced into the human population from an animal reservoir and culminating in a lethal epidemic in 2002-03, affecting 8,098 indi- viduals, 774 of whom died (9.6\%)(1). The virus shares $79 \%$ genome sequence identity with SARS-CoV-2, which is responsible for the current COVID-19 pandemic(2). SARS$\mathrm{CoV}$ can generate a rapid inflammatory cascade eventually leading to pneumonia or severe acute respiratory syndrome (SARS), characterized by diffuse alveolar damage, extensive disruption of epithelial cells and accumulation of reactive macrophages(3). Similar to SARS-CoV-2, SARS$\mathrm{CoV}$ spike protein $\mathrm{S}$ binds to angiotensin converting enzyme 2 (ACE2), which is widely expressed on the cell membrane of oral, lung, and nasal mucosa epithelial cells, arterial smooth muscle and venous endothelial cells, as well of other organs, including stomach, small intestine, colon, skin, lymph nodes, spleen, liver, kidney, and brain(4). Supportive care-including prevention of Acute Respiratory Distress Syndrome (ARDS), multi-organ failure, and secondary infections-remains the foundational approach for managing serious infections caused by coronaviruses, although preliminary analysis of a recently-reported, prospective, randomized, placebo-controlled trial, suggests that patients receiving remdesivir recovered faster than those receiving placebo(57). Despite early optimism and approval on May $1^{\text {st }}, 2020$ of remdesivir for emergency use in hospitalized patients with COVID-19, no other specific antiviral treatment has been proven to be effective in randomized, placebo-controlled trials $(5,6)$. Consequently, there remains a formidable unmet need to identify pharmacologic treatments, alone or in combination-directly targeting either viral mechanisms and/or host cell factors-that significantly inhibit viral replication and, by extension, minimize progression of target organ failure associated with COVID-19.

Current efforts focusing on antiviral drug discovery can be summarized as belonging to two broad strategies: (a) disrupting the synthesis and assembly of viral proteins or (b) targeting host proteins and mechanisms required by the viral replication cycle. The first strategy has yielded drugs targeting (i) viral proteases, required for processing of the virus large 
replicase polyprotein $1 \mathrm{a}$, producing non-structural proteins involved in viral transcription and replication $(5,8)$; (ii) RNAdependent RNA-polymerase, using guanosine and adenosine analogs, as well as acyclovir derivatives; (iii) virus helicases; (iv) viral spike proteins, with antibodies, peptide decoys and carbohydrate-binding agents; and (v) structural proteins such as those maintaining ion channel activity of $\mathrm{CoV}$ E protein and RNA-binding affinity of CoV N protein $(5,6,9,10)$. Although virus-targeting approaches have the advantage of being specific, and, therefore, generally offer acceptable toxicity profiles, targeting viral products typically restricts the applicability of antiviral agents to only one, or only a few, closely related virus species. Moreover, due to the high mutation rate of viral genomes, such drugs are prone to rapid virus adaptation by resistant strain selection $(11,12)$. Considering the time required to develop new pharmacologic agents, this strategy has proven unsuitable to address new viral epidemics and pandemics in real time.

In contrast, targeting host cell proteins, especially at an early stage when viral hijacking of host mechanisms may still be reversible, may have more universal and longer term value because the same host factors may be required by multiple, potentially unrelated viral species and because host target proteins mutate far less rapidly than viral proteins, thereby limiting emergence of drug resistance(13). Unfortunately, pharmacologic targeting of host factors is more commonly associated with toxicity, thereby limiting clinical application of many drugs identified as potential anti-viral agents in vitro, for instance, with anti-CoV drugs $E C_{50}$ markedly exceeding their maximum tolerated serum concentration $\left(C_{\max }\right)(5)$. Despite these translational challenges, current approaches to target host proteins are primarily based on either boosting innate anti-viral immune response, in particular interferon response, or targeting proteins and processes mediating viral infection, such as ACE2 receptors(14), cell surface and endosomal proteases(15), and clathrin mediated endocytosis(16). Moreover, broad availability of high-throughput screening approaches has allowed the purposing and repurposing of drugs based on their effect on virus replication(16-19), leading to identification of several anti-coronavirus candidates, such as chloroquine, tamoxifen, dasatinib and lopinavir, among others $(16,19)$. Yet, this approach is limited by the idiosyncratic nature of the in vitro models used in antiviral screens and by drug concentrations that may not be achievable in patients(5).

More recently, systems biology approaches, including temporal kinome analysis(20) and proteomics(21-24), have also been used to identify protein kinases - and associated pathways - modulated in response to virus infection, as well as to generate virus-host protein-protein interactomes (PPI). These methods also present an opportunity to develop and test hosttargeting therapeutic approaches that apply functional genomics to the "infected system as a whole."(24) The output of these predictions can be used to direct drug repurposing efforts(21-23) and to design more focused in vitro screens, with models that better recapitulate disease patho- physiology, such as primary cells, organoids or 3D organ-onchip systems(25).

Coronaviruses have been shown to extensively hijack the cellular machinery of host cells they infect; as one example, this class of viruses induces arrest in $\mathrm{S}$ phase, allowing them to benefit from physiological alterations they induce in host cells that enhance their reproductive rate(26). As shown for other physiologic(27-29) and pathologic cell states-among them, cancer(30-34), neurodegeneration(35, 36), and diabetes(29) — we propose that such transcriptionally "locked" states are established by the virus and maintained by a handful of Master Regulator (MR) proteins, organized within a highly auto-regulated protein module, or checkpoint (see Califano \& Alvarez(30) for a recent perspective). For simplicity, in a viral infection context, we will call such modules "ViroCheckpoints." Accordingly, we propose that aberrant, virus-mediated activation of a ViroCheckpoint is ultimately responsible for creating a transcriptionally "locked" cellular context that is primed for viral replication and release. We thus propose ViroCheckpoint activity reversal as a potentially valuable therapeutic strategy for pharmacologic intervention.

Here we show that time-dependent, SARS-CoV-mediated ViroCheckpoints-and the specific MR proteins of which they are comprised-can be effectively elucidated by network-based analysis using the Virtual Inference of Protein activity by Enriched Regulon (VIPER) algorithm(37). More importantly, once the MR protein identity is available, drugs can be effectively and reproducibly prioritized based on their ability to invert the activity of ViroCheckpoint MR proteins, using the OncoTreat algorithm(34), a NYS CLIA-certified algorithm that is used routinely on cancer patients at Columbia University.(38)

Accurate identification of virus-dependent MR proteins permits deployment of the same OncoTreat-based methodological approach for mechanism-based repurposing or development of new drugs with potential anti-viral activity. To avoid confusion, we will use the term "ViroTreat" to indicate the virus-specific version of OncoTreat. Specifically, ViroTreat uses the full repertoire of virus-induced MR proteins in the ViroCheckpoint as a reporter assay to identify drugs capable of reversing its activity(34), thereby preventing emergence of or abrogating the virus-mediated transcriptional locked state. While limited by the availability of data on SARS-CoV-2, including of infection in an appropriate pathophysiologic cell context, we provide proof of concept that this approach can be applied to prioritizing FDA-approved and late-stage investigational drugs representing potential antiviral agents for SARS-CoV based on infection in cancer-related lung epithelial cells.

\section{Results}

Elucidating MRs of SARS-CoV infection in lung epithelial cells. To identify candidate MR proteins that mechanisti- 
cally regulate the host cell gene expression signature induced by SARS-CoV infection (i.e. the SARS-CoV ViroCheckpoint), we applied the VIPER algorithm to a previouslypublished, microarray-based gene expression signature of a Calu-3 lung adenocarcinoma cell clone expressing elevated ACE2 levels, compared to the parental line, at $12 \mathrm{~h}, 24 \mathrm{~h}$, and $48 \mathrm{~h}$ following infection with SARS-CoV at MOI $=0.1(39)$. A total of 6,054 regulatory proteins were considered in the analysis, including 1,793 transcription factors (TFs), 656 cotranscription factors (co-TFs), and 3,755 signaling proteins (SP).

Similar to a highly-multiplexed gene reporter assay, VIPER measures the activity of an individual protein based on the enrichment of its positively regulated and repressed targets in genes that are over- and under-expressed in a specific cell state, compared to a control(37). We have shown that VIPER can accurately measure the activity of $>70 \%$ of regulatory proteins and, as a result, the algorithm has been used to elucidate MRs of both pathologic $(31-33,35,36,40,41)$ and physiologic cell states(27-29) that have been experimentally validated. Moreover, VIPER-inferred protein activity has been shown to provide a better biomarker of cell phenotype than the original transcriptional profile $(30,34,42,43)$; and, importantly, is a better reporter for validating clinically relevant drug sensitivity(44). Accordingly, VIPER requires a differential expression signature for each sample to be analyzed and a regulatory model comprising the transcriptional targets of each regulatory protein. For the former, we computed a differential gene expression signature for each SARS-CoV infected sample, by comparing it to three $12 \mathrm{~h}$ mock control replicates. For the latter, we leveraged a transcriptional regulatory model (interactome) generated by ARACNe(45) analysis of 517 samples in the lung adenocarcinoma cohort of The Cancer Genome Atlas (TCGA)(37). Use of a cancer-related interactome is well justified as we have shown that protein transcriptional targets are highly conserved between cancer and normal cells(28).

The analysis revealed $n=236$ proteins, whose activity was significantly affected by SARS-CoV infection in at least one time point $\left(p<10^{-5}\right.$, Bonferroni Corrected (BC), see Supplementary Table 1). Examination of the top 10 activated MR proteins at each of the evaluated time-points (Fig. 1a) revealed the presence of canonical cell-cycle regulators, including (a) cyclins (CCNA2), and other proteins involved in G1/S transition(46) (E2F8 and UHRF1); (b) S-phase proteins, such as topoisomerases (TOP2A(47)) and other factors involved in S-phase cell cycle arrest(48) (CHEK1, GTSE1); (c) mitotic checkpoint proteins(49) (BUB1B, KIF11 and NDC80); and (d) proteins involved in nucleotide synthesis (GMPS). These showed significant activation as early as $12 \mathrm{~h}$ after SARS$\mathrm{CoV}$ infection. In contrast, established innate immune response proteins were also found among the top activated MRs, including IFN-induced factors(50) (MX1, IRF9 and IFI27) but their activation became most evident only at the latest time point $(48 \mathrm{~h})$. Interestingly, some proteins previously identified as key tumor MRs were strongly activated,

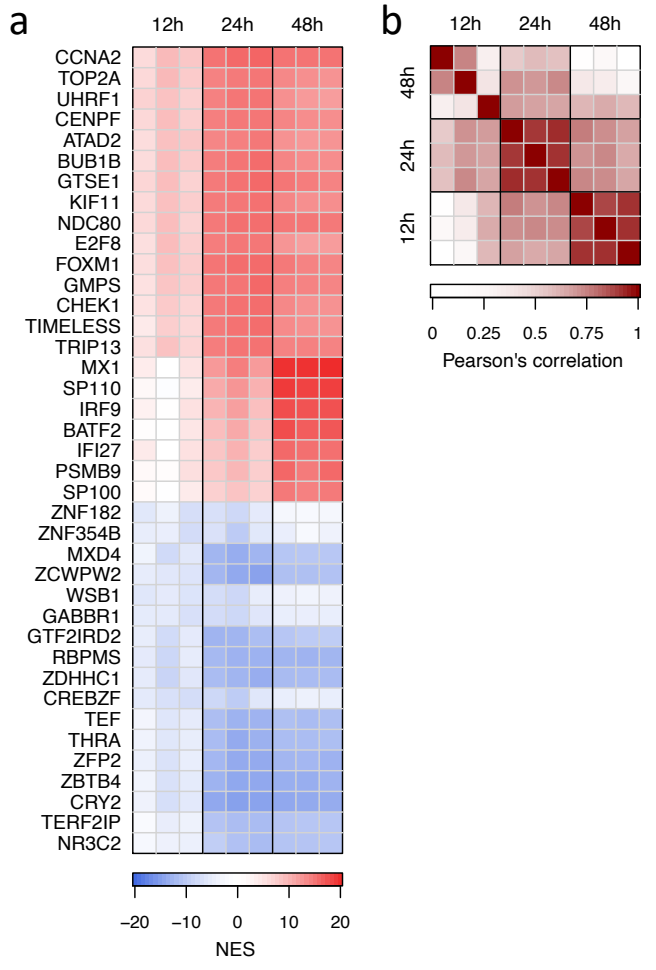

Fig. 1. SARS-CoV-induced ViroCheckpoint in Calu-3 lung adenocarcinoma cells. (a) Heatmap showing the VIPER-inferred protein activity, expressed as normalized enrichment score (NES), for the top 10 most activated and the top 10 most inactivated proteins in response to SARS-CoV infection for each of the three time points. (b) Heatmap showing the similarity between the SARS-CoV induced protein activity signatures, expressed as Pearson's correlation coefficient.

such as FOXM1 and $\operatorname{CENPF}(33,51)$, although this may be a byproduct of the cancer related nature of the Calu- 3 cells used in the infection assays.

We then systematically evaluated whether viral infection could affect host proteins known to be involved in SARS$\mathrm{CoV}$ host-pathogen protein-protein interactions (PPI). We based this analysis on a set of 36 proteins previously identified by high-throughput yeast-2-hybrid screen and validated by luciferase assays(23). Of the 36,12 were represented among our set of 6,054 regulons and could thus be assessed for enrichment in SARS-CoV-induced differentially active proteins. Despite the low statistical power of a test based on only 12 proteins, enrichment was statistically significant for the $12 \mathrm{~h}$ activity signature $(p<0.01$, Supplementary Fig. 1a). Enrichment was borderline non-significant at 24h ( $p=0.08)$, and not significant at $48 \mathrm{~h}$ (Supplementary Figs. $1 \mathrm{~b}$ and c).

To increase the test's sensitivity, we leveraged a larger set of proteins identified as PPI for 26 of the 29 proteins coded by the closely related SARS-CoV-2 virus, as identified by massspec analysis of pull-down assays(21). Of 332 host proteins identified by that analysis, 89 were represented among those analyzed by VIPER. Confirming the prior results, enrichment was highly significant $\left(p_{12 h}<10^{-5}\right.$ by 2 -tail aREA test(37); $p_{24 h}<0.01$ and $p_{48 h}<0.001$ by 1 -tail aREA test, see Supplementary Fig. 1g, k and 1, respectively). Interestingly, while enrichment was significant at all three time 
points, ( $p<0.01$, 1-tail aREA test, Supplementary Fig. 1 j1), several of the human SARS-CoV-2 PPIs activated at $12 \mathrm{~h}$ became inactivated at later time points (Supplementary Fig. 1h-i).

Correlation analysis showed a gradual shift in protein-activity signatures from $12 \mathrm{~h}$ to $48 \mathrm{~h}$ after infection (Fig. 1b), suggesting dynamic activation and inactivation of a diverse repertoire of genetic programs by virus-host interaction and thus dynamic transition across multiple, time-dependent ViroCheckpoints. To gain insight into the biological programs most profoundly affected by SARS-CoV infection, we performed Gene-Set Enrichment Analysis (GSEA)(52) of a set of 50 biologically-relevant hallmark gene-sets from $\operatorname{MSigDB}(53)$ in differentially active, infection-mediated proteins (Fig. 2). The analysis identified four time-dependent program classes including: (a) cell cycle programs, consistently up-regulated at all three time points; (b) immune-related programs, associated with interferon response, inflammatory response, TNF$\alpha$, and IL-6/JACK/STAT3 signaling, which were progressively upregulated over time; (c) DNA repair pathways and (d) PI3K/AKT/mTOR programs more strongly activated at 12h (Fig. 2).

Consistent with the multifarious effects that coronaviruses are known to exert through their complex, synchronized modulations of cell cycle progression, interferon antagonism, interleukin 6 and 8 induction, and host protein synthesis(26), these findings disclose a time-dependency, with early vs. late activation of protein signatures each linked to a distinct set of biofunctional hallmarks resulting from a virusgoverned reconfiguration of the host cell's regulatory state, with alterations in cell cycle during the initial post-infection phase, followed by a phase characterized by ignition of proinflammatory cytokine signaling pathways.

\section{ViroTreat analysis of SARS-CoV infected cells iden- tifies novel therapeutic targets for drug repurposing.} We have previously developed and validated a systematic approach (OncoTreat) for identifying drugs and compounds capable of reversing the aberrant activity of all Tumor Checkpoint MRs, representing mechanistic determinants of cell state, on a patient by patient basis(34). As a direct result of the high reproducibility demonstrated by VIPER,(37) the test has been certified by the NYS-CLIA laboratory and is available in the United States from the Columbia University Laboratory of Personalized Genomic Medicine(38); and, in China, from the Xiamen Encheng Group Ltd.

OncoTreat is used routinely to assess potential therapy for cancer patients who are progressing on standard of care, as part of the Columbia Precision Oncology Initiative(54). Despite the fact that it was originally developed for deployment and drug prioritization in the setting of precision oncology, the OncoTreat methodology is fully generalizable and can be applied to any state transition and any drug collection, including transitions related to and induced by viral infection. To avoid confusion, we will use the term ViroTreat to refer to the algorithm when used to identify antiviral drugs (see description in Fig. 3).

ViroTreat requires a tissue-matched drug perturbation database. For this analysis, we had previously generated a collection of RNASeq profiles of NCI-H1793 lung adenocarcinoma cells, at $24 \mathrm{~h}$ following treatment with a repertoire of 133 FDA approved and 195 late-stage (Phase 2 and 3) drugs-primarily used in or developed for the oncology setting - at their highest subtoxic concentration $(48 \mathrm{~h}$ $\left.I C_{20}\right)$ or maximum serum concentration $\left(C_{\max }\right)$, whichever is lower. RNASeq data was generated using a fully automated, 96-well based microfluidic technology called PLATESeq(55) (Supplementary Table 2). Selection of the NCIH1793 cell line as an adequate model for the analysis was based on the significant overlap of SARS-CoV infection MR proteins with proteins differentially activated in this cell line $\left(p<10^{-28}, 10^{-38}\right.$, and $10^{-24}$ at $12 \mathrm{~h}, 24 \mathrm{~h}$ and $48 \mathrm{~h}$ after infection, by 1-tail aREA test; see Supplementary Fig. 2). In addition, the main rationale for these assays is the elucidation of protein-level MoA of a drug repertoire and MoA is generally well-recapitulated in lineage matched cells(56).

Using this predictive model, ViroTreat prioritized 44 FDAapproved drugs and 49 investigational compounds in oncology, based on their ability to significantly invert the ViroCheckpoint protein activity signature, at one or more of the 3 evaluated time-points following infection $\left(p<10^{-10}\right.$, BC; see Supplementary Table 3). Based on this analysis, two FDA-approved drugs - the CDK inhibitor palbociclib and the MEK inhibitor trametinib-and 4 investigational compounds, including three MAP kinase and one AKT/CHEK1 inhibitors, were able to significantly invert the ViroCheckpoint activity at all three time-points $\left(p<10^{-10}, \mathrm{BC}\right.$, Fig. 4a). In addition, six FDA-approved drugs and seven investigational compounds demonstrated the capacity to invert the ViroCheckpoint protein activity pattern at the two earliest time points (12h and 24h, $p<10^{-10}$, BC, Fig. 4a); while two FDA-approved drugs - the ALK and EGFR inhibitors brigatinib and osimertinib - and five investigational compounds were predicted to significantly invert the MR signature identified at later time points (24h and 48h, $p<10^{-10}$, BC, Fig. 4a).

Consistent with the pathways enrichment analysis (Fig. 2), several drug families were enriched among the top ViroTreat predictions, including MAP kinases, PI3K/AKT/mTOR, CDK and other cell cycle-related drugs; HDAC and bromodomain protein inhibitors; proteasome and HSP90 inhibitors; and NF- $\kappa$ B and JAK inhibitors (Fig. 4a).

Of special clinical relevance in the context of the COVID-19 pandemic, ViroTreat independently identified the Selective Inhibitor of Nuclear Export (SINE) drug selinexor-FDAapproved for the treatment of relapsed or refractory multiple myeloma - as an extremely potent inverter of SARS-CoV induced ViroCheckpoint activity, in particular, at $12 \mathrm{~h}$ and $24 \mathrm{~h}$ time points after infection $\left(p_{12 h}<10^{-16}\right.$ and $p_{24 h}<10^{-19}$, BC, Fig. 4). 
a

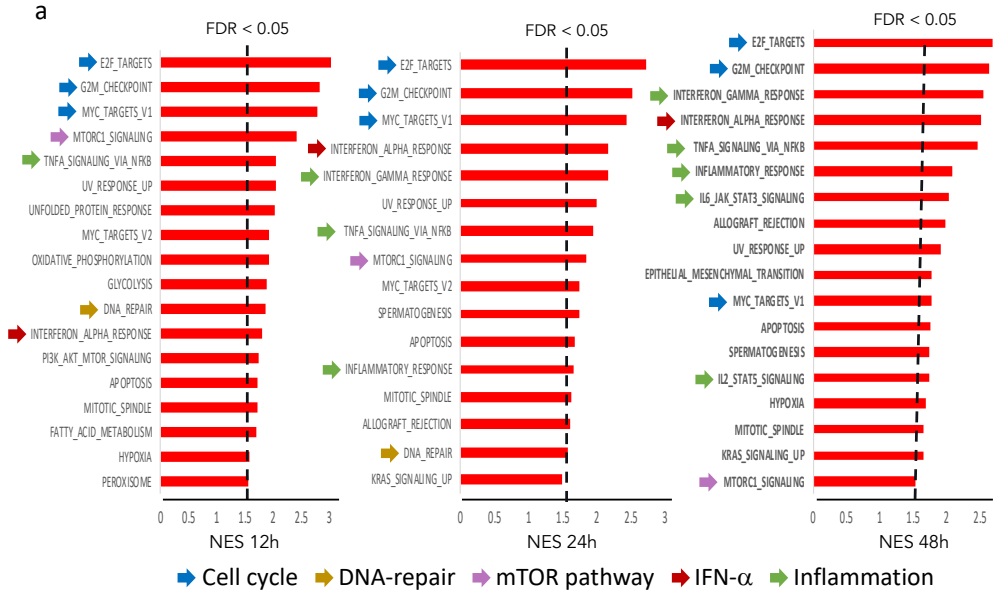

b

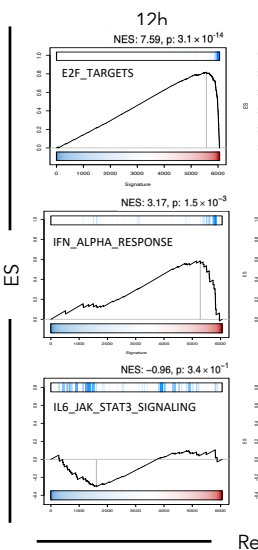

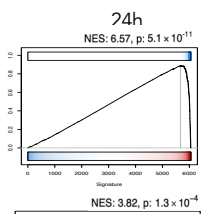

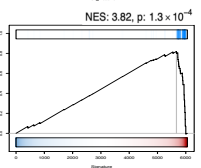

NES: 2.24, p: $2.5 \times 10^{-2}$

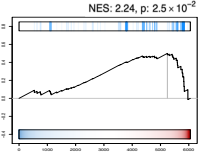

Regulatory protein activity

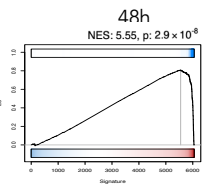

NES: $4.06,0: 4.9 \times 10^{-3}$
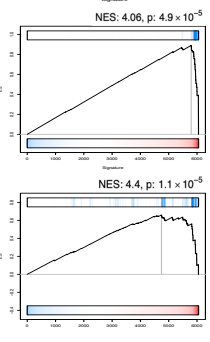

Fig. 2. Biological programs activated by SARS-CoV infection. (a) Hallmark gene-sets from MSigDB significantly enriched (FDR $<0.05$ ) in proteins activated at $12 \mathrm{~h}, 24 \mathrm{~h}$ and $48 \mathrm{~h}$ after SARS-CoV infection. The bars indicate the GSEA-estimated Normalized Enrichment Score (NES). Pathways and processes related to cell cycle progression and cell proliferation, DNA-repair, mTOR, IFN- $\alpha$ and inflammation are indicated by blue, yellow, purple, red and green arrows, respectively. (b) GSEA plots showing the enrichment of E2F-targets, IFN- $\alpha$-response and IL6/JAK/STAT pathway hallmark gene-sets on the differential activity of 6,054 regulatory proteins at $12 \mathrm{~h}$, $24 \mathrm{~h}$ and $48 \mathrm{~h}$ after SARS-CoV infection. The $x$-axis shows the regulatory proteins sorted from the most inactivated (left), to the most activated (right) in response to viral infection. The $y$-axis shows the enrichment score estimated by GSEA. The blue vertical lines indicate the proteins annotated as part of each of the analyzed biological programs/pathways.

\section{Discussion}

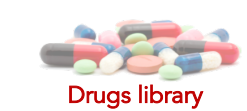

Drug-perturbation screen

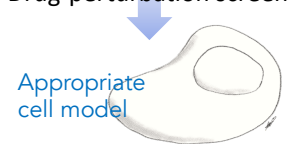

Expression profile PLATE-Seq

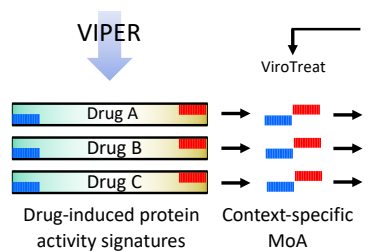

Fig. 3. ViroTreat diagram. ViroTreat requires two components: (A) a contextspecific drug Mechanism of Action (MoA) database, which is generated by perturbing an appropriate cell model with therapeutically relevant drug concentrations, followed by VIPER analysis of the drug-induced gene expression signatures and identification of the top most differentially active proteins, both activated and inactivated in response to the drug; and (B) the specific virus-induced protein activity signature-where the most differentially active proteins constitute the ViroCheckpoint-dissected by VIPER analysis of a gene expression signature, obtained by comparing an infected tissue or relevant model with non-infected mock controls. ViroTreat then predicts the effect of the drugs on the ViroCheckpoint by matching their MoA with the virus-induced protein activity signature, and quantifies the inverse enrichment using the aREA algorithm. The diagram shows 3 drugs, where only drug $\mathrm{B}$, by activating the host proteins that are being inactivated during virus infection, and inactivating the proteins that are being activated by the virus infection, effectively acts by inverting the ViroCheckpoint activity pattern; and, therefore, would be prioritized as a host cell-targeted antiviral therapeutic option.
ViroTreat presents an application of the extensively validated OncoTreat algorithm for targeting MR proteins driving virusmediated, reprogrammed cell states induced by viral hijacking of the host cell regulatory machinery. It also provides proof-of-concept of the ability to rapidly prioritize drugs capable of abrogating the reprogrammed, transcriptionallylocked state induced by viral infection, responsible for creating an environment permissive to viral replication and release. Our analysis identified 44 FDA-approved and 49 investigational agents capable of virtually abrogating the MR signature-the ViroCheckpoint protein activity patterninduced by SARS-CoV infection.

Consistent with the observation that coronaviruses interfere with cell cycle progression to benefit from the physiology of host cells arrested in S phase(26), we show SARS-CoV infection-induced activation of MRs involved in cell cycle progression and DNA repair pathways. Notably, it has been reported previously that coronaviruses inhibit the $\mathrm{pRb}$ tumor suppressor protein, inducing infected cell to progress rapidly from $G_{1}$ and to arrest the host cell in $S$ phase(57). SARS$\mathrm{CoV}$ further favors host cell arrest in $S$ phase by inhibiting CDK4 and CDK6 kinase activity(58). We also observed activation of PI3K/AKT/mTOR pathway proteins, suggesting that SARS-CoV-similar to other viruses(59), including +ssRNA viruses like chikungunya(60), hepatitis $C(61)$, west nile(62) and dengue(63), as well as other RNA respiratory viruses like influenza(64) and the respiratory syncytial virus(65) - might subvert mTOR pathway activity. Indeed, temporal kinome analysis of human hepatocytes infected with MERS-CoV had previously revealed changes in MAPK and PI3K/AKT/mTOR pathways(20). Finally, we observed activation of proteins involved in innate immunity, including interferon response and pro-inflammatory pathways, which have been also previously described for coronaviruses(26). 
bioRxiv preprint doi: https://doi.org/10.1101/2020.05.12.091256; this version posted May 17, 2020. The copyright holder for this preprint (which was not certified by peer review) is the author/funder, who has granted bioRxiv a license to display the preprint in perpetuity. It is made available under aCC-BY-ND 4.0 International license.

a

\begin{tabular}{|c|c|c|c|c|c|c|}
\hline Compound & FDA & Concentration & $12 \mathrm{~h}$ & $24 \mathrm{~h}$ & $48 \mathrm{~h}$ & Known targets \\
\hline Selinexor & Yes & $137 \mathrm{nM}$ & 16.19 & 19.74 & 6.44 & XPO1 \\
\hline Trametinib & Yes & $36 \mathrm{nM}$ & 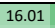 & 24.88 & 14.84 & MAP2K1, MAP2K2 \\
\hline Cobimetinib & Yes & $514 \mathrm{nM}$ & 14.47 & 20.61 & 3.23 & MAP2K1 \\
\hline PD0325901 & No & $667 \mathrm{nM}$ & 19.77 & 27.24 & 15.92 & MAP2K1 \\
\hline TAK-733 & No & $268 \mathrm{nM}$ & 17.61 & 25.3 & 9.02 & MAP2K1 \\
\hline Pimasertib & No & $911 \mathrm{nM}$ & 16.81 & 25.61 & 21.72 & MAP2K1, МАР2K2 \\
\hline Refametinib & No & $2.3 \mathrm{uM}$ & 12.45 & 19.13 & 11.13 & MAP2K1, MAP2K2 \\
\hline Binimetinib & No & $1 \mathrm{uM}$ & 7.56 & 17.67 & 13.27 & MAP2K2, МАP2K1 \\
\hline Everolimus & Yes & $84 \mathrm{nM}$ & 13.8 & 8.91 & 0 & mTOR \\
\hline Temsirolimus & Yes & $81 \mathrm{nM}$ & 10.9 & 7.88 & 0 & mTOR \\
\hline PI3KA Inhibitor IV & No & $1 \mathrm{um}$ & 15.48 & 21.12 & 9.93 & РІКЗСА \\
\hline Pictilisib & No & $599 \mathrm{nM}$ & 14.1 & 10.77 & 0 & PIKЗСА, PIK3CD \\
\hline CC-223 & No & $931 \mathrm{nM}$ & 13.81 & 7.52 & 0 & mTOR \\
\hline PF-04691502 & No & $147 \mathrm{nM}$ & 12.61 & 13.92 & 8.62 & Pan-PI3K, mTOR \\
\hline Pl-103 & No & $110 \mathrm{nM}$ & 12.46 & 17.81 & 7.79 & Pan-PI3K \\
\hline UCN-01 & No & $74 \mathrm{nM}$ & 12.06 & 17.89 & 11.75 & AKT1, PKC \\
\hline Palbociclib & Yes & $115 \mathrm{nM}$ & 18.49 & 23.5 & 15.76 & CDK4, CDK6 \\
\hline Dasatinib & Yes & $345 \mathrm{nM}$ & 14.09 & 13.58 & 0.8 & SRC, ABL1, BCR, KIT \\
\hline Erlotinib & Yes & $3.4 \mathrm{uM}$ & 11.49 & 9.2 & 1.32 & EGFR \\
\hline Brigatinib & Yes & $3.8 \mathrm{uM}$ & 5.93 & 19.54 & 18.69 & ALK, EGFR \\
\hline Osimertinib & Yes & $1.7 \mathrm{um}$ & 2.63 & 12.32 & 23.74 & EGFR \\
\hline Motesanib & No & $1.3 \mathrm{um}$ & 11.51 & 8.84 & 0 & FLT1, KDR, FLT4, KIT \\
\hline TAE684 & No & 5 uM & 8.81 & 23.29 & 24.23 & ALK \\
\hline Ki8751 & No & 5 uM & 9.69 & 19.46 & 7.52 & KDR \\
\hline Dovitinib & No & $591 \mathrm{nM}$ & 7.98 & 17.39 & 19.49 & FGFR3, FLT3, KIT, FGFR1 \\
\hline LY2835219 & No & $473 \mathrm{nM}$ & 6.4 & 16.84 & 21.95 & CDK4, CDK6 \\
\hline ENMD-2076 & No & $1.5 \mathrm{uM}$ & 5.64 & 16.76 & 23.45 & AURKC \\
\hline Gilteritinib & No & $2.3 \mathrm{um}$ & 3.26 & 8.61 & 11.17 & FLT3 \\
\hline Panobinostat & Yes & $45 \mathrm{nM}$ & 14.33 & 16.71 & 3.8 & pan-HDAC \\
\hline Belinostat & Yes & $2.5 \mathrm{uM}$ & 12.17 & 7.44 & 0 & pan-HDAC \\
\hline Resminostat & No & $4.4 \mathrm{um}$ & 18.43 & 18.86 & 6.31 & HDAC1, HDAC3, HDAC6 \\
\hline Rocilinostat & No & $1.5 \mathrm{um}$ & 12.14 & 5.36 & 0 & HDAC6 \\
\hline OTX015 & No & $3.9 \mathrm{um}$ & 1.81 & 11.75 & 18.19 & BRD2, BRD3, BRD4 \\
\hline Carfilzomib & Yes & $24 \mathrm{nM}$ & 10.94 & 19.4 & (5.87 & Proteasome \\
\hline SNX-2112 & No & $287 \mathrm{nM}$ & 9.51 & 16.84 & 9.58 & HSP90AA1, HSP90AB1 \\
\hline Luminespib & No & $1.1 \mathrm{uM}$ & 5.95 & 15.45 & 8.74 & HSP90AA1, HSP90AB1 \\
\hline Cyclosporine & $\overline{\text { Yes }}$ & $1.9 \mathrm{uM}$ & 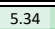 & 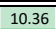 & 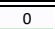 & PPP3R2 \\
\hline Bardoxolone Methyl & No & $145 \mathrm{nM}$ & 10.41 & 17.55 & 8.63 & CHUK, IKBKB, NFKB1, NFKB 2 \\
\hline Momelotinib & No & $1.6 \mathrm{uM}$ & 5.21 & 8.45 & 10.83 & JAK1, JAK2 \\
\hline Niclosamide & Yes & $500 \mathrm{nM}$ & 14.35 & 15.26 & 1.18 & Tapeworm \\
\hline Thapsigargin & No & $15 \mathrm{nM}$ & 8.23 & 21.32 & 19.56 & SERCA \\
\hline
\end{tabular}

b NES: $-8.9, p: 6.48 \mathrm{e}-17$

Nuclear export

MAP kinase

MAP kinase

CDKs

Cell cycle

PI3K / AKT / mTOR

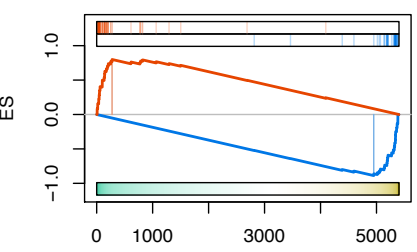

SCoV $12 \mathrm{~h}$ protein activity signature

C

NES: $-9.8, p: 1.84 e-20$

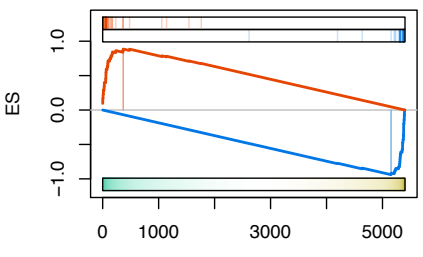

SCoV 24h protein activity signature

d NES: $-6, p: 3.59 e-07$

Chromatin remodeling

Protein metabolism Inflammation JAK/STAT

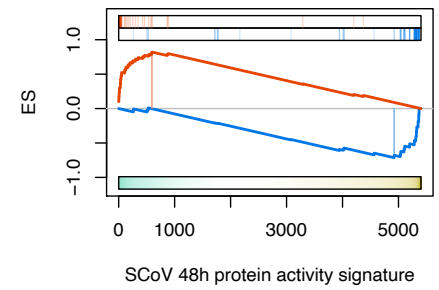

Fig. 4. Top drugs and compounds identified by ViroTreat. (a) Table of FDA-approved drugs and investigational compounds identified by ViroTreat as significantly inverting the pattern of activity of the SARS-CoV induced checkpoint $\left(p<10^{-10}, \mathrm{BC}\right)$ for at least one of the three analyzed time points, and being simultaneously significant $\left(p<10^{-5}\right.$, $\mathrm{BC}$ ) for at least another time point. The drugs and compounds were organized in blocks according to the biological role or pathway membership of their primary target protein. For each block, the drugs and compounds significant for each time point $\left(p<10^{-10}, \mathrm{BC}\right)$, were sorted by their ViroTreat significant level for $12 \mathrm{~h}$, followed by $24 \mathrm{~h}$ and $48 \mathrm{~h}$. FDA-approved drugs were reported prior to investigational compounds. The table also shows the concentration used to perturb $\mathrm{NCI}-\mathrm{H} 1793$ cells, the ViroTreat significance level, as - $\log _{10}$ ( $p$-value), BC, indicated by the green heatmap, and the primary target for each of the significant drugs and compounds. (b-d) GSEA plots showing the enrichment of the top 25 proteins most activated (red vertical lines), and the top 25 proteins most inactivated (blue vertical lines), in $\mathrm{NCl}-\mathrm{H} 1793 \mathrm{cells}$ in response to selinexor perturbation, on the protein activity signatures induced by SARS-CoV infection of Calu-3 cells (x-axis) for $12 \mathrm{~h}$ (b), $24 \mathrm{~h}$ (c) and $48 \mathrm{~h}$ (d). NES and $p$-value, estimated by 2 -tail aREA test, are indicated on top of each plot.

While formal experimental validation is still required, there are several positive indications this approach may be effective. Specifically, drugs for SARS-CoV most highly prioritized by ViroTreat were highly consistent, at least based on their primary target proteins, with biological programs and pathways known to be modulated by coronavirus infection $(26,66)$. Notably, in this regard, cell cycle progression/proliferation, PI3K/AKT/mTOR, innate immunity and inflammation are well represented among the primary target proteins for those pharmacologic agents strongly predicted by ViroTreat to possess host cell-targeted, antiviral effects.

A literature search revealed that many of the oncology drugs and compounds identified by ViroTreat have been considered previously for their potential antiviral effects. For instance, the MAPK inhibitor trametinib, one of the top ViroTreat hits for SARS-CoV, was shown to inhibit MERS-CoV replication in vitro $(5,20)$, as well as influenza $\mathrm{A}$ virus both in vitro and in vivo(67). Similarly, everolimus, an mTOR inhibitor identified by ViroTreat, has also been shown to inhibit MERS-CoV $(5,20)$ and cytomegalovirus $(68)$ replication in vitro, as well as to reduce incidence of cytomegalovirus infections following kidney transplant(69). Among tyrosine kinase inhibitors identified by ViroTreat, dasatinib was previously described to inhibit MERS-CoV(5, 19) and HIV-1(70) replication in vitro; while erlotinib was shown to inhibit dengue(71), hepatitis $C(72)$ and ebola(73) replication. The HSP90 inhibitors SNX-2112 and luminespib, as well as the sarco/endoplasmatic reticulum $\mathrm{Ca}^{2+}$ ATPase inhibitor thapsigargin, all identified by ViroTreat as inverters of the SARS$\mathrm{CoV}$ induced checkpoint, have been shown to inhibit herpes simplex(74), chikungunya(75), foot and mouth disease virus(76), respiratory syncytial virus(77), rhinovirus(78) and hepatitis A virus replication(79).

Finally, ViroTreat independently identified the SINE drug molecule selinexor-an FDA-approved agent for the treatment of relapsed or refractory multiple myeloma - as an extremely potent inverter of SARS-CoV-induced ViroCheckpoint activity. Selinexor is a potent and highly-specific inhibitor of XPO1 activity, which leads to nuclear retention of its cargo proteins containing leucine rich Nuclear Export Signals. Based on experimental studies performed by Karyopharm Therapeutics Inc., low Selinexor concentrations (leq $100 \mathrm{nM}$ ) inhibited viral replication by $90 \%$ in green monkey kidney Vero cells infected with SARS-CoV-2(80). As a result of these observations and data, which are consistent with the ViroTreat prioritization of selinexor we report in this study, a randomized, placebo-controlled Phase 2 clinical study (NCT04355676 and NCT04349098), evaluat- 
ing low dose oral selinexor in hospitalized patients with severe COVID-19 has been initiated and is currently enrolling patients, with results anticipated to be reported by August $31^{\text {st }}, 2020(80)$.

This analysis has several limitations that partially restrict its value as proof of concept. Specifically, infection was conducted in a cancer cell line, rather than in a more physiologically relevant context, such as in primary bronchial or alveolar epithelial cells. In addition, drug perturbations were also performed in a cancer cell line context, thus potentially introducing undesired confounding factors, even though use of mock controls for the infection, and vehicle control for the drug perturbations, from the same cancer cell line should have eliminated most of the cancer-related bias and cell line idiosyncrasies. As a result, extrapolation of this approach to the clinic may be limited by the following assumptions: (a) that the host cell regulatory checkpoint hijacked by the virus is conserved between the Calu-3 adenocarcinoma cell line and the normal alveolar or bronchial epithelial cells in vivo; and (2) that the drugs' and compounds' MoA is conserved between the NCI-H1793 lung adenocarcinoma cells and normal lung epithelial cells in vivo. Moreover, while for the generation of the perturbational data and the contextspecific MoA database we used subtoxic drug concentrations that, in most cases, were well below the maximum tolerated dose for all drugs and compounds, the relevant pharmacologic concentration for their deployment as antiviral therapy may be much lower than the original recommended concentration for their use as anti-cancer drugs.

Further research is necessary to benchmark the ViroTreat approach. Specifically, better reporters of SARS-CoV infection should be established, ideally directly from nasopharyngeal swabs or bronchial lavage of SARS-CoV patients. More relevant to the current pandemic, such samples are starting to emerge from COVID-19 patients and may lead to elucidation of critical entry points for COVID-19 therapeutic intervention. Similarly, drug profiles should be generated in a more physiologic context, including primary airway epithelial cells. It is also important to establish whether virusinduced transcriptional lock states are similar across all cell and tissue contexts infected by the virus, or whether the hijacked states are cell context-specific. Finally, appropriate environments for in vitro and in vivo validation of prioritized drugs should be developed(56).

To our knowledge, this is the first time a virus-induced MR module (i.e., the ViroCheckpoint) is proposed as a pharmacological target to abrogate the virus's ability to hijack the cellular machinery of host cells, a strategy that coronaviruses are known to employ to prime the host cell environment so it is amenable to viral replication and release(26). In addition, ViroTreat represents a unique method for the systematic and quantitative prioritization of mechanism-based, host-directed drugs capable of abrogating this critical, and previously unaddressed component of viral infection. If effectively validated, this approach presents several advantages: First, ViroTreat is tailored to target the entire repertoire of host pro- teins hijacked by the virus to create a permissive environment, rather than a single host or viral protein. As such, we anticipate drugs identified by ViroTreat to have more universal applications, including being effective against a broader viral repertoire, while also being more effective at eluding virus adaptation mechanisms arising from rapid mutation under drug selection stress. Indeed, drug-mediated reprogramming of host cell to a transcriptional state that confers resistance against coronavirus-induced reprogramming presents the opportunity to identify drugs that are potentially effective for a broader class of viruses, as long as they share similar pathobiological strategies for host cell takeover. Second, the ViroTreat analysis can be performed expeditiously-as soon as the ViroCheckpoint signature of a novel virus becomes available. Therefore, this methodology is especially well-suited to the urgency characteristic of epidemics and pandemics.

Developing effective treatments for respiratory tract infections-i.e., those that reduce such hard end points as hospitalization, need for mechanical ventilation, and mortality-exclusively through direct viral targeting has been historically challenging. Drugs identified specifically for host cell-targeting have the potential therapeutic advantage of acting in a mechanistically complementary-even synergistic - way with readily available antivirals, thereby suggesting roadmaps for developing and testing combination regimens that may mitigate viral replication by acting upon the infected system as a whole. Such multi-mechanistic pharmacologic approaches targeting both the virus and host cell proteins that are critically dysregulated as a result of viral infection may be required to optimize clinical outcomes, especially in challenging and vulnerable patients exposed to lethal pathogens with high virulence and viral load.

\section{ACKNOWLEDGEMENTS}

We thank Christopher Walker for reviewing selinexor data accuracy and Tatiana Alvarez for original artwork. This research was supported by the following $\mathrm{NIH}$ grants to Andrea Califano: R35 CA197745 (Outstanding Investigator Award); U01 CA217858 (Cancer Target Discovery and Development); S10 OD012351 and S10 OD021764 (Shared Instrument Grants).

Author Contributions. Conceptualization and Methodology, P.L., A.C. and M.J.A.; Investigation, P.L., X.S., G.B. and M.J.A.; Formal Analysis, P.L., X.S., Y.S., E.F.D. and M.J.A.; Experimental execution and data generation: C.K., R.R. and S.P.; Original Draft, G.B., A.C. and G.B.; Writing - Review and Editing, P.L., G.B., A.C. and M.J.A.

Competing Financial Interests Statement. P.L. is Director of Single-Cell Systems Biology at DarwinHealth, Inc., a company that has licensed some of the algorithms used in this manuscript from Columbia University. G.B. is founder, CEO and equity holder of DarwinHealth, Inc. X.S. is Senior Computational Biologist at DarwinHealth, Inc. A.C. is founder, equity holder, consultant, and director of DarwinHealth Inc. M.J.A. is CSO and equity holder of DarwinHealth, Inc. Columbia University is also an equity holder in DarwinHealth Inc. 
bioRxiv preprint doi: https://doi.org/10.1101/2020.05.12.091256; this version posted May 17, 2020. The copyright holder for this preprint (which was not certified by peer review) is the author/funder, who has granted bioRxiv a license to display the preprint in perpetuity. It is made available under aCC-BY-ND 4.0 International license.

\section{Bibliography}

1. Joseph S.M. Peiris, Kwok Y. Yuen, Albert D.M.E. Osterhaus, and Klaus Stöhr. The Severe Acute Respiratory Syndrome. New England Journal of Medicine, 349(25):2431-2441, dec 2003. ISSN 0028-4793. doi: 10.1056/NEJMra032498.

2. Na Zhu, Dingyu Zhang, Wenling Wang, Xingwang Li, Bo Yang, Jingdong Song, Xiang Zhao, Baoying Huang, Weifeng Shi, Roujian Lu, Peihua Niu, Faxian Zhan, Xuejun Ma, Dayan Wang, Wenbo Xu, Guizhen Wu, George F. Gao, Wenjie Tan, and China Novel Coronavirus Investigating and Research Team. A Novel Coronavirus from Patients with Pneumonia in China, 2019. The New England journal of medicine, 382(8):727-733, 2020. ISSN 15334406. doi: 10.1056/NEJMoa2001017.

3. John M Nicholls, Leo LM Poon, Kam C Lee, Wai F Ng, Sik T Lai, Chung Y Leung, Chung M Chu, Pak K Hui, Kong L Mak, Wilna Lim, Kin W Yan, Kwok H Chan, Ngai C Tsang, Yi Guan, Kwok Y Yuen, and JS Malik Peiris. Lung pathology of fatal severe acute respiratory syndrome. The Lancet, 361(9371):1773-1778, may 2003. ISSN 01406736. doi: 10.1016/S0140-6736(03)13413-7.

4. Wenhui Li, Chengsheng Zhang, Jianhua Sui, Jens H Kuhn, Michael J Moore, Shiwen Luo, Swee-Kee Wong, I-Chueh Huang, Keming Xu, Natalya Vasilieva, Akikazu Murakami, Yaqing $\mathrm{He}$, Wayne A Marasco, Yi Guan, Hyeryun Choe, and Michael Farzan. Receptor and viral determinants of SARS-coronavirus adaptation to human ACE2. The EMBO Journal, 24(8): 1634-1643, apr 2005. ISSN 0261-4189. doi: 10.1038/sj.emboj.7600640.

5. Alimuddin Zumla, Jasper F W Chan, Esam I. Azhar, David S C Hui, and Kwok-Yung Yuen. Coronaviruses - drug discovery and therapeutic options. Nature reviews. Drug discovery, 15(5):327-47, may 2016. ISSN 1474-1784. doi: 10.1038/nrd.2015.37.

6. James M Sanders, Marguerite L Monogue, Tomasz Z Jodlowski, and James B Cutrell. Pharmacologic Treatments for Coronavirus Disease 2019 (COVID-19): A Review. JAMA, apr 2020. ISSN 1538-3598. doi: 10.1001/jama.2020.6019.

7. NIAID. NIH Clinical Trial Shows Remdesivir Accelerates Recovery from Advanced COVID19, 2020.

8. Yahira M. Báez-Santos, Sarah E. St. John, and Andrew D. Mesecar. The SARS-coronavirus papain-like protease: Structure, function and inhibition by designed antiviral compounds. Antiviral Research, 115:21-38, mar 2015. ISSN 01663542. doi: 10.1016/j.antiviral.2014.12. 015 .

9. Guangdi Li and Erik De Clercq. Therapeutic options for the 2019 novel coronavirus (2019nCoV). Nature reviews. Drug discovery, 19(3):149-150, 2020. ISSN 1474-1784. doi: 10.1038/d41573-020-00016-0.

10. Adeyemi O. Adedeji and Stefan G. Sarafianos. Antiviral drugs specific for coronaviruses in preclinical development. Current Opinion in Virology, 8:45-53, 2014. ISSN 18796265. doi: 10.1016/j.coviro.2014.06.002.

11. Nila J. Dharan. Infections With Oseltamivir-Resistant Influenza $A(\mathrm{H} 1 \mathrm{~N} 1)$ Virus in the United States. JAMA, 301(10):1034, mar 2009. ISSN 0098-7484. doi: 10.1001/jama.2009.294.

12. Nelson Lee and Aeron C. Hurt. Neuraminidase inhibitor resistance in influenza. Current Opinion in Infectious Diseases, 31(6):520-526, dec 2018. ISSN 0951-7375. doi: $10.1097 /$ QCO.0000000000000498.

13. Simonides I. van de Wakker, Marcel J E Fischer, and Ronald S. Oosting. New drugstrategies to tackle viral-host interactions for the treatment of influenza virus infections. European journal of pharmacology, 809:178-190, aug 2017. ISSN 1879-0712. doi: 10.1016/j.ejphar.2017.05.038.

14. Dong P. Han, Adam Penn-Nicholson, and Michael W. Cho. Identification of critical determinants on ACE2 for SARS-CoV entry and development of a potent entry inhibitor. Virology, 350(1):15-25, jun 2006. ISSN 00426822. doi: 10.1016/j.virol.2006.01.029.

15. Yanchen Zhou, Punitha Vedantham, Kai Lu, Juliet Agudelo, Ricardo Carrion, Jerritt W. Nunneley, Dale Barnard, Stefan Pöhlmann, James H. McKerrow, Adam R. Renslo, and Graham Simmons. Protease inhibitors targeting coronavirus and filovirus entry. Antiviral Research, 116:76-84, apr 2015. ISSN 01663542. doi: 10.1016/j.antiviral.2015.01.011.

16. Adriaan $\mathrm{H}$ de Wilde, Dirk Jochmans, Clara C. Posthuma, Jessika C. Zevenhoven-Dobbe, Stefan van Nieuwkoop, Theo M. Bestebroer, Bernadette $G$ van den Hoogen, Johan Neyts, and Eric J. Snijder. Screening of an FDA-approved compound library identifies four smallmolecule inhibitors of Middle East respiratory syndrome coronavirus replication in cell culture. Antimicrobial agents and chemotherapy, 58(8):4875-84, aug 2014. ISSN 1098-6596. doi: 10.1128/AAC.03011-14.

17. Miao Xu, Emily M. Lee, Zhexing Wen, Yichen Cheng, Wei-Kai Huang, Xuyu Qian, Julia Tcw, Jennifer Kouznetsova, Sarah C. Ogden, Christy Hammack, Fadi Jacob, Ha Nam Nguyen, Misha Itkin, Catherine Hanna, Paul Shinn, Chase Allen, Samuel G. Michael, Anton Simeonov, Wenwei Huang, Kimberly M. Christian, Alison Goate, Kristen J. Brennand, Ruil Huang, Menghang Xia, Guo-Li Ming, Wei Zheng, Hongjun Song, and Hengli Tang. Identification of small-molecule inhibitors of Zika virus infection and induced neural cell death via a drug repurposing screen. Nature medicine, 22(10):1101-1107, oct 2016. ISSN 1546-170X. doi: $10.1038 / \mathrm{nm} .4184$

18. Lisa M. Johansen, Jennifer M. Brannan, Sue E. Delos, Charles J. Shoemaker, Andrea Stossel, Calli Lear, Benjamin G. Hoffstrom, Lisa Evans Dewald, Kathryn L. Schornberg, Corinne Scully, Joseph Lehár, Lisa E. Hensley, Judith M. White, and Gene G. Olinger. FDA-approved selective estrogen receptor modulators inhibit Ebola virus infection. Science translational medicine, 5(190):190ra79, jun 2013. ISSN 1946-6242. doi: 10.1126/scitranslmed.3005471.

19. Julie Dyall, Christopher M. Coleman, Brit J. Hart, Thiagarajan Venkataraman, Michael R. Holbrook, Jason Kindrachuk, Reed F. Johnson, Gene G. Olinger, Peter B. Jahrling, Monique Laidlaw, Lisa M. Johansen, Calli M. Lear-Rooney, Pamela J. Glass, Lisa E. Hensley, and Matthew B. Frieman. Repurposing of clinically developed drugs for treatment of Middle East respiratory syndrome coronavirus infection. Antimicrobial agents and chemotherapy, 58(8): 4885-93, aug 2014. ISSN 1098-6596. doi: 10.1128/AAC.03036-14.

20. Jason Kindrachuk, Britini Ork, Brit J. Hart, Steven Mazur, Michael R. Holbrook, Matthew B. Frieman, Dawn Traynor, Reed F. Johnson, Julie Dyall, Jens H. Kuhn, Gene G. Olinger, Lisa E Hensley, and Peter B Jahrling. Antiviral potential of ERK/MAPK and PI3K/AKT/mTOR signaling modulation for Middle East respiratory syndrome coronavirus infection as identified by temporal kinome analysis. Antimicrobial agents and chemotherapy, 59(2):1088-99, feb 2015. ISSN 1098-6596. doi: 10.1128/AAC.03659-14.

21. David E Gordon, Gwendolyn M Jang, Mehdi Bouhaddou, Jiewei Xu, Kirsten Obernier, Kris M. White, Matthew J. O'Meara, Veronica V Rezelj, Jeffrey Z Guo, Danielle L Swaney, Tia A. Tummino, Ruth Huettenhain, Robyn M Kaake, Alicia L Richards, Beril Tutuncuoglu, Helene Foussard, Jyoti Batra, Kelsey Haas, Maya Modak, Minkyu Kim, Paige Haas, Benjamin J. Polacco, Hannes Braberg, Jacqueline M Fabius, Manon Eckhardt, Margaret Soucheray, Melanie J Bennett, Merve Cakir, Michael J. McGregor, Qiongyu Li, Bjoern Meyer, Ferdinand Roesch, Thomas Vallet, Alice Mac Kain, Lisa Miorin, Elena Moreno, Zun Zar Chi Naing, Yuan Zhou, Shiming Peng, Ying Shi, Ziyang Zhang, Wenqi Shen, Ilsa T Kirby, James E Melnyk, John S. Chorba, Kevin Lou, Shizhong A. Dai, Inigo Barrio-Hernandez, Danish Memon, Claudia Hernandez-Armenta, Jiankun Lyu, Christopher J. P. Mathy, Tina Perica, Kala B. Pilla, Sai J. Ganesan, Daniel J. Saltzberg, Ramachandran Rakesh, Xi Liu, Sara B. Rosenthal, Lorenzo Calviello, Srivats Venkataramanan, Jose Liboy-Lugo, Yizhu Lin, Xi-Ping Huang, YongFeng Liu, Stephanie A. Wankowicz, Markus Bohn, Maliheh Safari, Fatima S. Ugur, Cassandra Koh, Nastaran Sadat Savar, Quang Dinh Tran, Djoshkun Shengjuler, Sabrina J Fletcher, Michael C. O'Neal, Yiming Cai, Jason C J Chang, David J Broadhurst, Saker Klippsten, Phillip P Sharp, Nicole A. Wenzell, Duygu Kuzuoglu, HaoYuan Wang, Raphael Trenker, Janet M. Young, Devin A. Cavero, Joseph Hiatt, Theodore L Roth, Ujjwal Rathore, Advait Subramanian, Julia Noack, Mathieu Hubert, Robert M. Stroud, Alan D. Frankel, Oren S. Rosenberg, Kliment A Verba, David A. Agard, Melanie Ott, Michael Emerman, Natalia Jura, Mark von Zastrow, Eric Verdin, Alan Ashworth, Olivier Schwartz, Christophe D'Enfert, Shaeri Mukherjee, Matt Jacobson, Harmit S Malik, Danica G Fujimori, Trey Ideker, Charles S Craik, Stephen N Floor, James S. Fraser, John D Gross, Andrej Sali, Bryan L Roth, Davide Ruggero, Jack Taunton, Tanja Kortemme, Pedro Beltrao, Marco Vignuzzi, Adolfo García-Sastre, Kevan M Shokat, Brian K. Shoichet, and Nevan J. Krogan. A SARS-CoV-2 protein interaction map reveals targets for drug repurposing. Nature, apr 2020. ISSN 0028-0836. doi: 10.1038/s41586-020-2286-9.

22. Yadi Zhou, Yuan Hou, Jiayu Shen, Yin Huang, William Martin, and Feixiong Cheng Network-based drug repurposing for novel coronavirus 2019-nCoV/SARS-CoV-2. Cell discovery, 6:14, 2020. ISSN 2056-5968. doi: 10.1038/s41421-020-0153-3.

23. Susanne Pfefferle, Julia Schöpf, Manfred Kögl, Caroline C. Friedel, Marcel A. Müller, Javier Carbajo-Lozoya, Thorsten Stellberger, Ekatarina von Dall'Armi, Petra Herzog, Stefan Kallies, Daniela Niemeyer, Vanessa Ditt, Thomas Kuri, Roland Züst, Ksenia Pumpor, Rolf Hilgenfeld, Frank Schwarz, Ralf Zimmer, Imke Steffen, Friedemann Weber, Volker Thiel, Georg Herrler, Heinz-Jürgen Thiel, Christel Schwegmann-Wessels, Stefan Pöhlmann, Jürgen Haas, Christian Drosten, and Albrecht von Brunn. The SARS-coronavirus-host interactome: identification of cyclophilins as target for pan-coronavirus inhibitors. PLoS pathogens, 7(10):e1002331, oct 2011. ISSN 1553-7374. doi: 10.1371/journal.ppat.1002331.

24. Hugh D. Mitchell, Amie J. Eisfeld, Amy C. Sims, Jason E. McDermott, Melissa M. Matzke, Bobbi-Jo M Webb-Robertson, Susan C. Tilton, Nicolas Tchitchek, Laurence Josset, Chengjun Li, Amy L. Ellis, Jean H. Chang, Robert A. Heegel, Maria L. Luna, Athena A. Schepmoes, Anil K. Shukla, Thomas O. Metz, Gabriele Neumann, Arndt G. Benecke, Richard D. Smith, Ralph S. Baric, Yoshihiro Kawaoka, Michael G. Katze, and Katrina M. Waters. A network integration approach to predict conserved regulators related to pathogenicity of influenza and SARS-CoV respiratory viruses. PloS one, 8(7):e69374, 2013. ISSN 1932-6203. doi: 10.1371/journal.pone.0069374.

25. Janick D Stucki, Nina Hobi, Artur Galimov, Andreas O. Stucki, Nicole Schneider-Daum, Claus-Michael Lehr, Hanno Huwer, Manfred Frick, Manuela Funke-Chambour, Thomas Geiser, and Olivier T. Guenat. Medium throughput breathing human primary cell alveoluson-chip model. Scientific reports, 8(1):14359, dec 2018. ISSN 2045-2322. doi: 10.1038/ s41598-018-32523-x.

26. Adriaan $\mathrm{H}$ de Wilde, Eric $\mathrm{J}$ Snijder, Marjolein Kikkert, and Martijn $\mathrm{J}$ van Hemert. Host Factors in Coronavirus Replication. Current topics in microbiology and immunology, 419 (October):1-42, 2012. ISSN 0070-217X. doi: 10.1007/82_2017_25.

27. Ritu Kushwaha, Nirmala Jagadish, Manjunath Kustagi, Mark J. Tomishima, Geetu Mendiratta, Mukesh Bansal, Hyunjae R. Kim, Pavel Sumazin, Mariano J. Alvarez, Celine Lefebvre, Patricia Villagrasa-Gonzalez, Agnes Viale, James E. Korkola, Jane Houldsworth, Darren R. Feldman, George J. Bosl, Andrea Califano, and R. S. K. Chaganti. Interrogation of a contextspecific transcription factor network identifies novel regulators of pluripotency. Stem cells (Dayton, Ohio), 33(2):367-77, feb 2015. ISSN 1549-4918. doi: 10.1002/stem.1870.

28. Celine Lefebvre, Presha Rajbhandari, Mariano J Alvarez, Pradeep Bandaru, Wei Keat Lim, Mai Sato, Kai Wang, Pavel Sumazin, Manjunath Kustagi, Brygida C Bisikirska, Katia Basso, Pedro Beltrao, Nevan Krogan, Jean Gautier, Riccardo Dalla-Favera, and Andrea Califano. A human B-cell interactome identifies MYB and FOXM1 as master regulators of proliferation in germinal centers. Molecular systems biology, 6(377):377, jun 2010. ISSN 1744-4292. doi: $10.1038 / \mathrm{msb} .2010 .31$.

29. Jinsook Son, Hongxu Ding, Domenico Accii, and Andrea Califano. AFF3 and BACH2 are master regulators of metabolic inflexibility, beta/alpha-cell transition, and dedifferentiation in type 2 diabetes. bioRxiv, page 768135, sep 2019. doi: 10.1101/768135.

30. Andrea Califano and Mariano J Alvarez. The recurrent architecture of tumour initiation, progression and drug sensitivity. Nature reviews. Cancer, 17(2):116-130, dec 2017. ISSN 1474-1768. doi: 10.1038/nrc.2016.124.

31. Maria Stella Carro, Wei Keat Lim, Mariano Javier Alvarez, Robert J Bollo, Xudong Zhao, Evan Y Snyder, Erik P Sulman, Sandrine L Anne, Fiona Doetsch, Howard Colman, Anna Lasorella, Ken Aldape, Andrea Califano, and Antonio lavarone. The transcriptional network for mesenchymal transformation of brain tumours. Nature, 463(7279):318-25, jan 2010. ISSN 1476-4687. doi: 10.1038/nature08712.

32. Presha Rajbhandari, Gonzalo Lopez, Claudia Capdevila, Beatrice Salvatori, Jiyang Yu, Ruth Rodriguez-Barrueco, Daniel Martinez, Mark Yarmarkovich, Nina Weichert-Leahey, Brian J. Abraham, Mariano J. Alvarez, Archana lyer, Jo Lynne Harenza, Derek Oldridge, Katleen De Preter, Jan Koster, Shahab Asgharzadeh, Robert C. Seeger, Jun S. Wei, Javed Khan, Jo Vandesompele, Pieter Mestdagh, Rogier Versteeg, A. Thomas Look, Richard A. Young, Antonio lavarone, Anna Lasorella, Jose M. Silva, John M. Maris, and Andrea Califano. Cross-Cohort Analysis Identifies a TEAD4-MYCN Positive Feedback Loop as the Core Regulatory Element of High-Risk Neuroblastoma. Cancer discovery, 8(5):582-599, may 2018. ISSN 2159-8290. doi: 10.1158/2159-8290.CD-16-0861. 
bioRxiv preprint doi: https://doi.org/10.1101/2020.05.12.091256; this version posted May 17, 2020. The copyright holder for this preprint (which was not certified by peer review) is the author/funder, who has granted bioRxiv a license to display the preprint in perpetuity. It is made available under aCC-BY-ND 4.0 International license.

33. Alvaro Aytes, Antonina Mitrofanova, Celine Lefebvre, Mariano J. Alvarez, Mireia CastilloMartin, Tian Zheng, James A. Eastham, Anuradha Gopalan, Kenneth J. Pienta, Michael M. Shen, Andrea Califano, and Cory Abate-Shen. Cross-species regulatory network analysis identifies a synergistic interaction between FOXM1 and CENPF that drives prostate cancer malignancy. Cancer cell, 25(5):638-51, may 2014. ISSN 1878-3686. doi: 10.1016/j.ccr. 2014.03.017.

34. Mariano J Alvarez, Prem S Subramaniam, Laura H Tang, Adina Grunn, Mahalaxmi Aburi, Gabrielle Rieckhof, Elena V Komissarova, Elizabeth A Hagan, Lisa Bodei, Paul A Clemons, Filemon S Dela Cruz, Deepti Dhall, Daniel Diolaiti, Douglas A Fraker, Afshin Ghavami, Daniel Kaemmerer, Charles Karan, Mark Kidd, Kyoung M Kim, Hee C Kim, Lakshmi P Kunju, Ülo Langel, Zhong Li, Jeeyun Lee, Hai Li, Virginia LiVolsi, Roswitha Pfragner, Allison R Rainey, Ronald B Realubit, Helen Remotti, Jakob Regberg, Robert Roses, Anil Rustgi, Antonia R Sepulveda, Stefano Serra, Chanjuan Shi, Xiaopu Yuan, Massimo Barberis, Roberto Bergamaschi, Arul M Chinnaiyan, Tony Detre, Shereen Ezzat, Andrea Frilling, Merten Hommann, Dirk Jaeger, Michelle K Kim, Beatrice S Knudsen, Andrew L Kung, Emer Leahy, David C Metz, Jeffrey W Milsom, Young S Park, Diane Reidy-Lagunes, Stuart Schreiber, Kay Washington, Bertram Wiedenmann, Irvin Modlin, and Andrea Califano. A precision oncology approach to the pharmacological targeting of mechanistic dependencies in neuroendocrine tumors. Nature genetics, 50(7):979-989, jul 2018. ISSN 1546-1718. doi: 10.1038/s41588-018-0138-4.

35. Burcin Ikiz, Mariano J Alvarez, Diane B Ré, Virginia Le Verche, Kristin Politi, Francesco Lotti, Sudarshan Phani, Radhika Pradhan, Changhao Yu, Gist F Croft, Arnaud Jacquier, Christopher E Henderson, Andrea Califano, and Serge Przedborski. The Regulatory Machinery of Neurodegeneration in In Vitro Models of Amyotrophic Lateral Sclerosis. Cell reports, 12(2): 335-45, jul 2015. ISSN 2211-1247. doi: 10.1016/j.celrep.2015.06.019.

36. Lars Brichta, William Shin, Vernice Jackson-Lewis, Javier Blesa, Ee-Lynn Yap, Zachary Walker, Jack Zhang, Jean-Pierre Roussarie, Mariano J Alvarez, Andrea Califano, Serge Przedborski, and Paul Greengard. Identification of neurodegenerative factors using translatome-regulatory network analysis. Nature neuroscience, 18(9):1325-33, sep 2015. ISSN 1546-1726. doi: 10.1038/nn.4070.

37. Mariano J Alvarez, Yao Shen, Federico M Giorgi, Alexander Lachmann, B Belinda Ding, $B$ Hilda Ye, and Andrea Califano. Functional characterization of somatic mutations in cancer using network-based inference of protein activity. Nature genetics, 48(8):838-47, aug 2016 ISSN 1546-1718. doi: 10.1038/ng.3593.

38. Columbia University. Darwin OncoTarget and OncoTreat, 2018.

39. Tomoki Yoshikawa, Terence E. Hill, Naoko Yoshikawa, Vsevolod L. Popov, Cristi L. Galindo, Harold R. Garner, C. J. Peters, and Chien-Te Kent Tseng. Dynamic innate immune responses of human bronchial epithelial cells to severe acute respiratory syndromeassociated coronavirus infection. PloS one, 5(1):e8729, jan 2010. ISSN 1932-6203. doi: 10.1371/journal.pone.0008729.

40. Logan A. Walsh, Mariano J. Alvarez, Erich Y. Sabio, Marsha Reyngold, Vladimir Makarov, Suranjit Mukherjee, Ken-Wing Lee, Alexis Desrichard, Sevin Turcan, Martin G. Dalin, Vinagolu K. Rajasekhar, Shuibing Chen, Linda T. Vahdat, Andrea Califano, and Timothy A. Chan. An Integrated Systems Biology Approach Identifies TRIM25 as a Key Determinant of Breast Cancer Metastasis. Cell reports, 20(7):1623-1640, aug 2017. ISSN 2211-1247. doi: 10.1016/j.celrep.2017.07.052.

41. Vez Repunte-Canonigo, William Shin, Leandro F Vendruscolo, Celine Lefebvre, Lena van der Stap, Tomoya Kawamura, Joel E Schlosburg, Mariano Alvarez, George F Koob, Andrea Califano, and Pietro Paolo Sanna. Identifying candidate drivers of alcohol dependence-induced excessive drinking by assembly and interrogation of brainspecific regulatory networks. Genome biology, 16(1):68, 2015. ISSN 1474-760X. doi: 10.1186/s13059-015-0593-5.

42. Hongxu Ding, Eugene F. Douglass, Adam M. Sonabend, Angeliki Mela, Sayantan Bose, Christian Gonzalez, Peter D. Canoll, Peter A. Sims, Mariano J. Alvarez, and Andrea Califano. Quantitative assessment of protein activity in orphan tissues and single cells using the metaVIPER algorithm. Nature communications, 9(1):1471, apr 2018. ISSN 2041-1723. doi: 10.1038/s41467-018-03843-3.

43. Evan O. Paull, Alvaro Aytes, Prem Subramaniam, Federico M. Giorgi, Eugene F. Douglass, Brennan Chu, Sunny J. Jones, Siyuan Zheng, Roel Verhaak, Cory Abate-Shen, Mariano J. Alvarez, and Andrea Califano. A Modular Master Regulator Landscape Determines the Impact of Genetic Alterations on the Transcriptional Identity of Cancer Cells. bioRxiv, page 758268, 2019. doi: 10.1101/758268.

44. Ajai Chari, Dan T Vogl, Maria Gavriatopoulou, Ajay K Nooka, Andrew J Yee, Carol A Huff, Philippe Moreau, David Dingli, Craig Cole, Sagar Lonial, Meletios Dimopoulos, A Keith Stewart, Joshua Richter, Ravi Vij, Sascha Tuchman, Marc S Raab, Katja C Weisel, Miche Delforge, Robert F Cornell, David Kaminetzky, James E Hoffman, Luciano J Costa, Terri L Parker, Moshe Levy, Martin Schreder, Nathalie Meuleman, Laurent Frenzel, Mohamad Mohty, Sylvain Choquet, Gary Schiller, Raymond L Comenzo, Monika Engelhardt, Thomas Illmer, Philip Vlummens, Chantal Doyen, Thierry Facon, Lionel Karlin, Aurore Perrot, Klaus Podar, Michael G Kauffman, Sharon Shacham, Lingling Li, Shijie Tang, Carla Picklesimer, Jean-Richard Saint-Martin, Marsha Crochiere, Hua Chang, Samir Parekh, Yose Landesman, Jatin Shah, Paul G Richardson, and Sundar Jagannath. Oral SelinexorDexamethasone for Triple-Class Refractory Multiple Myeloma. The New England journal of medicine, 381(8):727-738, aug 2019. ISSN 1533-4406. doi: 10.1056/NEJMoa1903455.

45. Katia Basso, Adam a Margolin, Gustavo Stolovitzky, Ulf Klein, Riccardo Dalla-Favera, and Andrea Califano. Reverse engineering of regulatory networks in human B cells. Nature genetics, 37(4):382-90, apr 2005. ISSN 1061-4036. doi: 10.1038/ng 1532 .

46. Cosetta Bertoli, Jan M. Skotheim, and Robertus A. M. de Bruin. Control of cell cycle transcription during G1 and S phases. Nature Reviews Molecular Cell Biology, 14(8):518-528, aug 2013. ISSN 1471-0072. doi: 10.1038/nrm3629.

47. James C. Wang. Cellular roles of DNA topoisomerases: a molecular perspective. Nature Reviews Molecular Cell Biology, 3(6):430-440, jun 2002. ISSN 1471-0072. doi: 10.1038/ nrm831.

48. Jiri Bartek and Jiri Lukas. Mammalian G1- and S-phase checkpoints in response to DNA damage. Current Opinion in Cell Biology, 13(6):738-747, dec 2001. ISSN 09550674. doi: 10.1016/S0955-0674(00)00280-5.
49. Markus Löbrich and Penny A. Jeggo. The impact of a negligent G2/M checkpoint on genomic instability and cancer induction. Nature Reviews Cancer, 7(11):861-869, nov 2007. ISSN 1474-175X. doi: 10.1038/nrc2248.

50. David E Levy, Isabelle J Marié, and Joan E Durbin. Induction and function of type I and III interferon in response to viral infection. Current Opinion in Virology, 1(6):476-486, dec 2011. ISSN 18796257. doi: 10.1016/j.coviro.2011.11.001.

51. Brygida Bisikirska, Mukesh Bansal, Yao Shen, Julie Teruya-Feldstein, Raju Chaganti, and Andrea Califano. Elucidation and Pharmacological Targeting of Novel Molecular Drivers of Follicular Lymphoma Progression. Cancer research, 76(3):664-74, feb 2016. ISSN 15387445. doi: 10.1158/0008-5472.CAN-15-0828.

52. Aravind Subramanian, Pablo Tamayo, Vamsi K Mootha, Sayan Mukherjee, Benjamin L Ebert, Michael a Gillette, Amanda Paulovich, Scott L Pomeroy, Todd R Golub, Eric S Lander, and Jill P Mesirov. Gene set enrichment analysis: a knowledge-based approach for interpreting genome-wide expression profiles. Proceedings of the National Academy of Sciences of the United States of America, 102(43):15545-50, oct 2005. ISSN 0027-8424. doi: 10.1073/pnas.0506580102.

53. Arthur Liberzon, Chet Birger, Helga Thorvaldsdóttir, Mahmoud Ghandi, Jill P. Mesirov, and Pablo Tamayo. The Molecular Signatures Database Hallmark Gene Set Collection. Cell Systems, 1(6):417-425, dec 2015. ISSN 24054712. doi: 10.1016/j.cels.2015.12.004.

54. Columbia University. Columbia Precision Oncology Initiative, 2018.

55. Erin C. Bush, Forest Ray, Mariano J. Alvarez, Ronald Realubit, Hai Li, Charles Karan, Andrea Califano, and Peter A. Sims. PLATE-Seq for genome-wide regulatory network analysis of high-throughput screens. Nature communications, 8(1):105, jul 2017. ISSN 2041-1723. doi: 10.1038/s41467-017-00136-z.

56. Mariano J Alvarez, Pengrong Yan, Mary L Alpaugh, Michaela Bowden, Ewa Sicinska, Chensheng W Zhou, Charles Karan, Ronald B Realubit, Prabhjot S Mundi, Adina Grunn, Dirk Jäger, John A Chabot, Antonio T Fojo, Paul E Oberstein, Hanina Hibshoosh, Jeffrey W Milsom, Matthew H Kulke, Massimo Loda, Gabriela Chiosis, Diane L Reidy-Lagunes, and Andrea Califano. Unbiased Assessment of H-STS cells as high-fidelity models for gastroenteropancreatic neuroendocrine tumor drug mechanism of action analysis. bioRxiv, page 677435, jun 2019. doi: 10.1101/677435.

57. Kanchan Bhardwaj, Pinghua Liu, Julian L Leibowitz, and C Cheng Kao. The coronavirus endoribonuclease Nsp15 interacts with retinoblastoma tumor suppressor protein. Journal of virology, 86(8):4294-304, apr 2012. ISSN 1098-5514. doi: 10.1128/JVI.07012-11.

58. Milan Surjit, Boping Liu, Vincent T K Chow, and Sunil K Lal. The nucleocapsid protein of severe acute respiratory syndrome-coronavirus inhibits the activity of cyclin-cyclindependent kinase complex and blocks $S$ phase progression in mammalian cells. The Journal of biological chemistry, 281(16):10669-81, apr 2006. ISSN 0021-9258. doi: 10.1074/jbc.M509233200.

59. Valerie Le Sage, Alessandro Cinti, Raquel Amorim, and Andrew J. Mouland. Adapting the Stress Response: Viral Subversion of the mTOR Signaling Pathway. Viruses, 8(6), jun 2016. ISSN 1999-4915, doi: 10.3390/v8060152.

60. Bastian Thaa, Roberta Biasiotto, Kai Eng, Maarit Neuvonen, Benjamin Götte, Lara Rheinemann, Margit Mutso, Age Utt, Finny Varghese, Giuseppe Balistreri, Andres Merits, Tero Ahola, and Gerald M McInerney. Differential Phosphatidylinositol-3-Kinase-Akt-mTOR Activation by Semliki Forest and Chikungunya Viruses Is Dependent on nsP3 and Connected to Replication Complex Internalization. Journal of virology, 89(22):11420-37, nov 2015. ISSN 1098-5514. doi: 10.1128/JVI.01579-15.

61. Lu Peng, Dongyu Liang, Wenyan Tong, Jianhua Li, and Zhenghong Yuan. Hepatitis C virus NS5A activates the mammalian target of rapamycin (mTOR) pathway, contributing to cell survival by disrupting the interaction between FK506-binding protein 38 (FKBP38) and mTOR. The Journal of biological chemistry, 285(27):20870-81, jul 2010. ISSN 1083-351X. doi: 10.1074/jbc.M110.112045.

62. Katherine D Shives, Erica L Beatman, Mastooreh Chamanian, Caitlin O'Brien, Jody Hobson-Peters, and J David Beckham. West nile virus-induced activation of mammalian target of rapamycin complex 1 supports viral growth and viral protein expression. Journal of virology, 88(16):9458-71, aug 2014. ISSN 1098-5514. doi: 10.1128/JVI.01323-14.

63. Chyan-Jang Lee, Ching-Len Liao, and Yi-Ling Lin. Flavivirus activates phosphatidylinositol 3-kinase signaling to block caspase-dependent apoptotic cell death at the early stage of virus infection. Journal of virology, 79(13):8388-99, jul 2005. ISSN 0022-538X. doi: 10. 1128/JVI.79.13.8388-8399.2005

64. Yeun-Kyung Shin, Qiang Liu, Suresh K Tikoo, Lorne A Babiuk, and Yan Zhou. Effect of the phosphatidylinositol 3-kinase/Akt pathway on influenza A virus propagation. The Journal of general virology, 88(Pt 3):942-50, mar 2007. ISSN 0022-1317. doi: 10.1099/vir.0.82483-0.

65. A P Duarte de Souza, D Nascimento de Freitas, K E Antuntes Fernandes, M D'Avila da Cunha, J L Antunes Fernandes, R Benetti Gassen, T Fazolo, L A Pinto, M Scotta, R Mattiello, P M Pitrez, C Bonorino, and R T Stein. Respiratory syncytial virus induces phosphorylation of mTOR at ser2448 in CD8 T cells from nasal washes of infected infants. Clinical and experimental immunology, 183(2):248-57, feb 2016. ISSN 1365-2249. doi: $10.1111 /$ cei. 12720 .

66. To Sing Fung and Ding Xiang Liu. Human Coronavirus: Host-Pathogen Interaction. An nual review of microbiology, 73(1):529-557, 2019. ISSN 1545-3251. doi: 10.1146/ annurev-micro-020518-115759.

67. Tobias Schräder, Sabine E. Dudek, André Schreiber, Christina Ehrhardt, Oliver Planz, and Stephan Ludwig. The clinically approved MEK inhibitor Trametinib efficiently blocks influenza A virus propagation and cytokine expression. Antiviral research, 157(July):80-92, 2018. ISSN 1872-9096. doi: 10.1016/j.antiviral.2018.07.006.

68. Long Tan, Noriaki Sato, Atsuko Shiraki, Motoko Yanagita, Yoshihiro Yoshida, Yoshinori Takemura, and Kimiyasu Shiraki. Everolimus delayed and suppressed cytomegalovirus DNA synthesis, spread of the infection, and alleviated cytomegalovirus infection. Antiviral research, 162(September 2018):30-38, 2019. ISSN 1872-9096. doi: 10.1016/j.antiviral.2018. 12.004

69. Paolo Malvezzi, Thomas Jouve, and Lionel Rostaing. Use of Everolimus-based Immunosuppression to Decrease Cytomegalovirus Infection After Kidney Transplant. Experimental and clinical transplantation : official journal of the Middle East Society for Organ Transplantation, 14(4):361-6, aug 2016. ISSN 2146-8427. doi: 10.6002/ect.2015.0292. 
bioRxiv preprint doi: https://doi.org/10.1101/2020.05.12.091256; this version posted May 17, 2020. The copyright holder for this preprint (which was not certified by peer review) is the author/funder, who has granted bioRxiv a license to display the preprint in perpetuity. It is made available under aCC-BY-ND 4.0 International license.

70. Mercedes Bermejo, María Rosa López-Huertas, Javier García-Pérez, Núria Climent, Benjamin Descours, Juan Ambrosioni, Elena Mateos, Sara Rodríguez-Mora, Lucía Rus-Bercial, Monsef Benkirane, José M Miró, Montserrat Plana, José Alcamí, and Mayte Coiras. Dasatinib inhibits HIV-1 replication through the interference of SAMHD1 phosphorylation in CD4+ T cells. Biochemical pharmacology, 106:30-45, apr 2016. ISSN 1873-2968. doi: 10.1016/j.bcp.2016.02.002

71. Szu-Yuan Pu, Fei Xiao, Stanford Schor, Elena Bekerman, Fabio Zanini, Rina BarouchBentov, Claude M Nagamine, and Shirit Einav. Feasibility and biological rationale of repurposing sunitinib and erlotinib for dengue treatment. Antiviral research, 155:67-75, 2018. ISSN 1872-9096. doi: 10.1016/j.antiviral.2018.05.001.

72. Gregory Neveu, Amotz Ziv-Av, Rina Barouch-Bentov, Elena Berkerman, Jon Mulholland, and Shirit Einav. AP-2-associated protein kinase 1 and cyclin G-associated kinase regulate hepatitis $C$ virus entry and are potential drug targets. Journal of virology, 89(8):4387-404, apr 2015. ISSN 1098-5514. doi: 10.1128/JVI.02705-14.

73. Elena Bekerman, Gregory Neveu, Ana Shulla, Jennifer Brannan, Szu-Yuan Pu, Stanley Wang, Fei Xiao, Rina Barouch-Bentov, Russell R. Bakken, Roberto Mateo, Jennifer Govero, Claude M. Nagamine, Michael S. Diamond, Steven De Jonghe, Piet Herdewijn, John M. Dye, Glenn Randall, and Shirit Einav. Anticancer kinase inhibitors impair intracellular viral trafficking and exert broad-spectrum antiviral effects. The Journal of clinical investigation, 127(4):1338-1352, apr 2017. ISSN 1558-8238 doi: 10.1172/JCI89857.

74. Yang-Fei Xiang, Chui-Wen Qian, Guo-Wen Xing, Jing Hao, Min Xia, and Yi-Fei Wang. Antiherpes simplex virus efficacies of 2-aminobenzamide derivatives as novel HSP90 inhibitors. Bioorganic \& medicinal chemistry letters, 22(14):4703-6, jul 2012. ISSN 1464-3405. doi: 10.1016/j.bmcl.2012.05.079.

75. Abhay P S Rathore, Timothy Haystead, Pratyush K Das, Andres Merits, Mah-Lee Ng, and Subhash $\mathrm{G}$ Vasudevan. Chikungunya virus $\mathrm{nsP} 3$ \& nsP4 interacts with $\mathrm{HSP}-90$ to promote virus replication: HSP-90 inhibitors reduce CHIKV infection and inflammation in vivo. Antiviral research, 103:7-16, mar 2014. ISSN 1872-9096. doi: 10.1016/j.antiviral.2013.12.010.

76. Joseph Newman, Amin S Asfor, Stephen Berryman, Terry Jackson, Stephen Curry, and Tobias J Tuthill. The Cellular Chaperone Heat Shock Protein 90 Is Required for Foot-andMouth Disease Virus Capsid Precursor Processing and Assembly of Capsid Pentamers. Journal of virology, 92(5), 2018. ISSN 1098-5514. doi: 10.1128/JVI.01415-17.

77. Rui Cui, Yizhuo Wang, Liu Wang, Guiming Li, Ke Lan, Ralf Altmeyer, and Gang Zou. Cyclopiazonic acid, an inhibitor of calcium-dependent ATPases with antiviral activity against human respiratory syncytial virus. Antiviral research, 132:38-45, 2016. ISSN 1872-9096. doi: 10.1016/j.antiviral.2016.05.010

78. Aline Schögler, Oliver Caliaro, Melanie Brügger, Blandina I Oliveira Esteves, Izabela Nita, Amiq Gazdhar, Thomas Geiser, and Marco P Alves. Modulation of the unfolded protein response pathway as an antiviral approach in airway epithelial cells. Antiviral research, 162:44-50, 2019. ISSN 1872-9096. doi: 10.1016/j.antiviral.2018.12.007.

79. Nan Nwe Win, Tatsuo Kanda, Masato Nakamura, Shingo Nakamoto, Hiroaki Okamoto, Osamu Yokosuka, and Hiroshi Shirasawa. Free fatty acids or high-concentration glucose enhances hepatitis A virus replication in association with a reduction in glucose-regulated protein 78 expression. Biochemical and biophysical research communications, 483(1):694699, 2017. ISSN 1090-2104. doi: 10.1016/j.bbrc.2016.12.080.

80. Karyopharm Therapeutics Inc. Karyopharm Announces Dosing of First Patient in Randomized Study Evaluating Low Dose Selinexor in Patients with Severe COVID-19, 2020.

81. Alexander Dobin, Carrie A. Davis, Felix Schlesinger, Jorg Drenkow, Chris Zaleski, Sonali Jha, Philippe Batut, Mark Chaisson, and Thomas R. Gingeras. STAR: ultrafast universal RNA-seq aligner. Bioinformatics (Oxford, England), 29(1):15-21, jan 2013. ISSN 13674811. doi: 10.1093/bioinformatics/bts635.

82. Michael I Love, Wolfgang Huber, and Simon Anders. Moderated estimation of fold change and dispersion for RNA-seq data with DESeq2. Genome biology, 15(12):550, 2014. ISSN 1474-760X. doi: 10.1186/s13059-014-0550-8.

83. G K Smyth. Linear models and empirical Bayes methods for assessing differential expression in microarray experiments. Statistical Applications in Genetics and Molecular Biology, 3(1):Art3, 2004

\section{Methods}

Cell lines. NCI-H1793 cells were obtained from ATCC (CRL5896), mycoplasm tested and maintained in DMEM:F12 medium supplemented with $5 \mu \mathrm{g} / \mathrm{ml}$ insulin, $10 \mu \mathrm{g} / \mathrm{ml}$ transferrin, $30 \mathrm{nM}$ sodium selenite, $10 \mathrm{nM} \beta$-estradiol, $4.5 \mathrm{mM}$ L-glutamine and $5 \%$ fetal bovine serum. Cells were grown in a humidified incubator at $37^{\circ} \mathrm{C}$ and $5 \% \mathrm{CO}_{2}$.

Lung epithelium context-specific drug mechanism of action database. The drug-perturbation dataset was generated as follows. First, the $E D_{20}$ for each of the 133 FDA-approved drugs and 195 investigational compounds in oncology was estimated in NCIH1793 cells by performing 10-point dose-response curves in triplicate, using total ATP content as read-out. Briefly, 2,000 cells per well were plated in 384-well plates. Small-molecule compounds were added with a $96-$ well pin-tool head $12 \mathrm{~h}$ after cell plating. Viable cells were quantified $48 \mathrm{~h}$ later by ATP assay (CellTiterGlo,
Promega). Relative cell viability was computed using matched DMSO control wells as reference. $E D_{20}$ was estimated by fitting a four-parameter sigmoid model to the titration results. NCI-H1793 cells, plated in 384-well plates, were then perturbed with a library of 328 FDA-approved drugs and small-molecule compounds at their corresponding $E D_{20}$ concentration. Cells were lysed at $24 \mathrm{~h}$ after small-molecule compound perturbation and the transcriptome was profiled by PLATE-Seq(55). RNA-Seq reads were mapped to the human reference genome assembly 38 using the STAR aligner(81). Expression data were then normalized by equivariance transformation, based on the negative binomial distribution with the DESeq Rsystem package (Bioconductor(82)). At least two replicates for each condition were obtained. Differential gene expression signatures were computed by comparing each condition with plate-matched vehicle control samples using a moderated Student's t-test as implemented in the limma package from Bioconductor(83). Individual gene expression signatures were then transformed into protein activity signatures with the VIPER algorithm(37), based on the a lung adenocarcinoma context-specific regulatory network available from the aracne.networks package from Bioconductor.

Computational analysis. Enrichment of gene-sets for biological hallmarks was performed using Gene Set Enrichment Analysis(52) with the Molecular Signatures Database MSigDB v7.1(53). Enrichment analysis for virus-interacting host proteins (PPI) on SARS-CoV induced protein activity signatures, as well as the OncoMatch(56) analysis to assess the conservation of the virusinduced MR protein activity on NCI-H1793 lung adenocarcinoma cells were performed with the aREA algorithm(37).

ViroTreat analysis. ViroTreat was performed by computing the enrichment of the top/bottom 50 most differentially active proteins in response to drug perturbation - the context-specific mechanism of action - on the virus-induced protein activity signature using the aREA algorithm(37). P-values for significantly negative enrichment were estimated using 1-tail aREA analysis, and multiple hypothesis testing was controlled by the Bonferroni's correction.

Code availability. All the code used in this work is freely available for research purposes. VIPER and aREA algorithms are part of the "viper" R-system's package available from Bioconductor. The lung adenocarcinoma context-specific interactome is available as part of the "aracne.networks" R-system's package from Bioconductor. 


\section{Supplementary Figures and Tables}

a

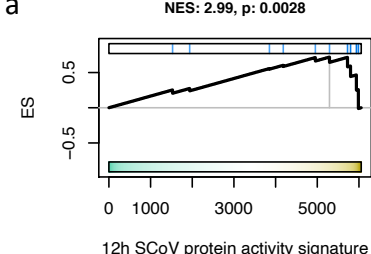

b

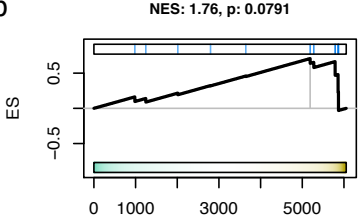

$24 \mathrm{~h} \mathrm{SCoV}$ protein activity signature

C

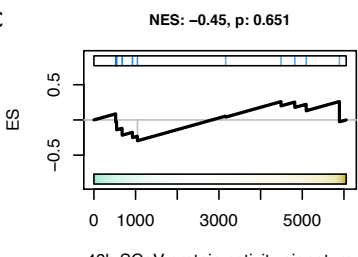

d

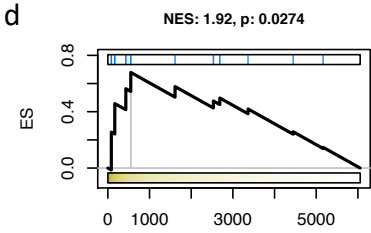

$12 \mathrm{~h} \mathrm{SCoV}$ differentially active proteins

e

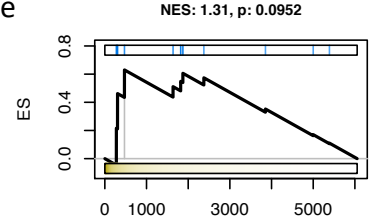

$24 \mathrm{~h} \mathrm{SCoV}$ differentially active proteins

f

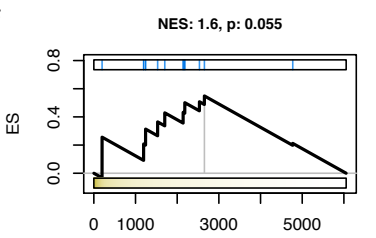

$48 \mathrm{~h} \mathrm{SCoV}$ differentially active proteins g

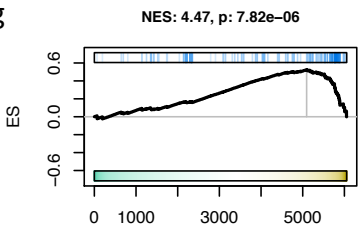

$12 \mathrm{~h} \mathrm{SCoV}$ protein activity signature

h

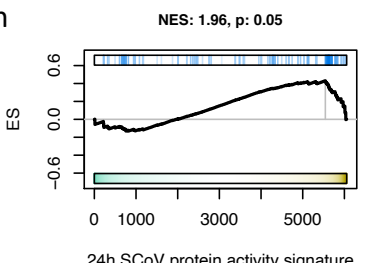

i

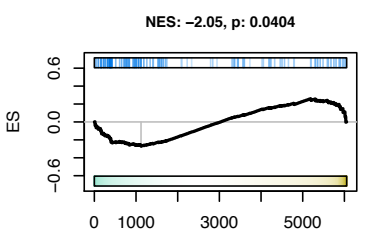

$48 \mathrm{~h} \mathrm{SCoV}$ protein activity signature

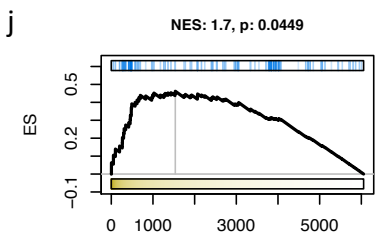

$12 \mathrm{~h} \mathrm{SCoV}$ differentially active proteins

k

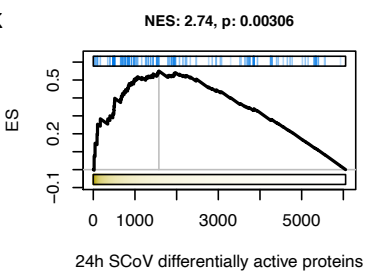

I

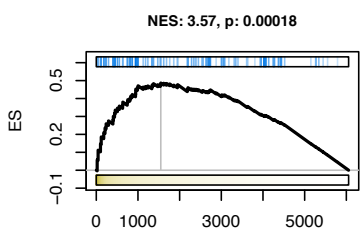

$48 \mathrm{~h}$ SCoV differentially active proteins

Supplementary Figure 1. Enrichment of SARS-CoV- and SARS-CoV2-interacting host proteins among the most differentially active proteins after SARS-CoV infection. (a-f) Enrichment of 12 SARS-CoV-interacting host proteins, or (g-l) 89 SARS-CoV2-interacting proteins on SARS-CoV induced protein activity signatures at $12 \mathrm{~h}(\mathrm{a}, \mathrm{d}, \mathrm{g}$ and $\mathrm{j}), 24 \mathrm{~h}(\mathrm{~b}, \mathrm{e}, \mathrm{h}$ and $\mathrm{k})$ and $48 \mathrm{~h} \mathrm{(c,} \mathrm{f,} \mathrm{i} \mathrm{and} \mathrm{l)} \mathrm{after} \mathrm{infection.} \mathrm{GSEA} \mathrm{plots} \mathrm{show} \mathrm{the} \mathrm{enrichment} \mathrm{score} \mathrm{(y-axis)} \mathrm{and} \mathrm{the} \mathrm{SARS-CoV} \mathrm{induced} \mathrm{protein} \mathrm{activ-}$ ity signature (x-axis), where 6,054 regulatory proteins were rank-sorted from the one showing the strongest inactivation (left) to the one showing the strongest activation (right) in response to SARS-CoV infection (a-c and g-i); or where the regulatory proteins were sorted from the most differentially active (left) to the least differentially active (right) after SARS-CoV infection. NES and $p$-value were estimated by 2 -tail aREA test and shown on top of each plot.
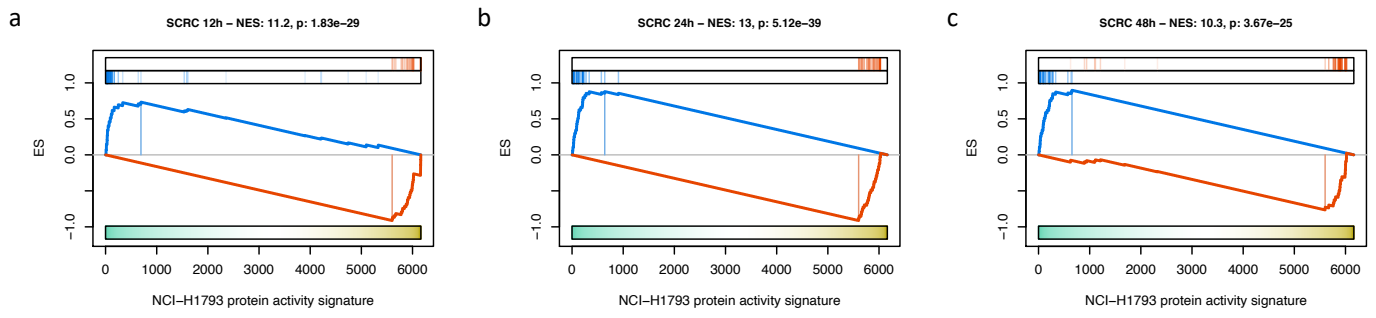

Supplementary Figure 2. Conservation of the SARS-CoV induced checkpoint in NCI-H1793 cells. GSEA plots for the enrichment of the top 25 most activated proteins (red vertical lines), and top 25 most inactivated proteins (blue vertical lines) by SARS-CoV infection at $12 \mathrm{~h}$ (a), $24 \mathrm{~h}$ (b) and $48 \mathrm{~h}$ (c) after infection. The $\mathrm{x}$-axis shows 6,054 proteins rank-sorted from the most inactivated ones (left) to the most activated ones (right) in NCI-H1793 cells when compared against 86 non-small cell lung cancer cell lines. The y-axis shows the GSEA enrichment score. NES and $p$-value, estimated by 2-tail aREA test, are indicated on top of each plot. 
bioRxiv preprint doi: https://doi.org/10.1101/2020.05.12.091256; this version posted May 17, 2020. The copyright holder for this preprint (which was not certified by peer review) is the author/funder, who has granted bioRxiv a license to display the preprint in perpetuity. It is made available under aCC-BY-ND 4.0 International license.

Supplementary Table 1. Proteins differentially active in response to SARS-CoV infection. Shown are 236 proteins differentially active $\left(p<10^{-5}, \mathrm{BC}, 2\right.$-tail aREA test) at any of the three evaluated time points. The table includes the EntrezID, and symbol of the genes coding for the differentially active proteins, the VIPER-inferred NES and Bonferroni's corrected p-value.

\begin{tabular}{|c|c|c|c|c|c|c|c|c|}
\hline \multirow[b]{2}{*}{ GenelD } & \multirow[b]{2}{*}{ Symbol } & & NES & & p-value, $B$ & onferroni's & corrected & \\
\hline & & $12 \mathrm{~h}$ & $24 \mathrm{~h}$ & $48 \mathrm{~h}$ & $12 \mathrm{~h}$ & 24h & $48 \mathrm{~h}$ & Description \\
\hline 890 & CCNA2 & 8.73 & 13.36 & 12.96 & $1.57 E-14$ & $6.33 E-37$ & $1.18 \mathrm{E}-34$ & cyclin A2 \\
\hline 7153 & TOP2A & 8.67 & 12.36 & 11.26 & $2.65 \mathrm{E}-14$ & $2.48 \mathrm{E}-31$ & $1.22 \mathrm{E}-25$ & DNA topoisomerase II alpha \\
\hline 29128 & UHRF1 & 8.45 & 12.5 & 10.59 & $1.80 \mathrm{E}-13$ & $4.76 E-32$ & $1.96 \mathrm{E}-22$ & ubiquitin like with PHD and ring finger domains 1 \\
\hline 1063 & CENPF & 8.45 & 12.48 & 11.5 & $1.83 \mathrm{E}-13$ & $5.76 E-32$ & $8.06 \mathrm{E}-27$ & centromere protein $\mathrm{F}$ \\
\hline 29028 & ATAD2 & 8.41 & 12.11 & 10.83 & $2.55 \mathrm{E}-13$ & $5.70 E-30$ & $1.54 \mathrm{E}-23$ & ATPase family AAA domain containing 2 \\
\hline 701 & BUB1B & 8.39 & 12.79 & 11.52 & $2.88 \mathrm{E}-13$ & $1.07 E-33$ & $6.28 \mathrm{E}-27$ & BUB1 mitotic checkpoint serine/threonine kinase B \\
\hline 51512 & GTSE1 & 8.39 & 12.97 & 12.37 & 2.97E-13 & $1.12 E-34$ & $2.20 \mathrm{E}-31$ & G2 and S-phase expressed 1 \\
\hline 3832 & KIF11 & 8.29 & 12.69 & 11.4 & $6.76 \mathrm{E}-13$ & $4.29 E-33$ & $2.55 E-26$ & kinesin family member 11 \\
\hline 10403 & NDC80 & 8.26 & 12.91 & 12.71 & $8.83 E-13$ & $2.40 E-34$ & $3.02 \mathrm{E}-33$ & NDC80 kinetochore complex component \\
\hline 79733 & E2F8 & 8.21 & 12.49 & 10.41 & $1.38 \mathrm{E}-12$ & $4.86 \mathrm{E}-32$ & $1.33 \mathrm{E}-21$ & E2F transcription factor 8 \\
\hline 2305 & FOXM1 & 8.16 & 13.14 & 12.13 & $1.97 \mathrm{E}-12$ & $1.17 E-35$ & $4.49 \mathrm{E}-30$ & forkhead box M1 \\
\hline 9232 & PTTG1 & 7.89 & 12.43 & 12.01 & $1.84 \mathrm{E}-11$ & $1.13 E-31$ & $1.83 \mathrm{E}-29$ & PTTG1 regulator of sister chromatid separation, securin \\
\hline 8833 & GMPS & 7.86 & 12.97 & 12 & $2.38 \mathrm{E}-11$ & $1.14 E-34$ & $2.17 \mathrm{E}-29$ & guanine monophosphate synthase \\
\hline 79723 & SUV39H2 & 7.8 & 12.21 & 11.35 & $3.61 \mathrm{E}-11$ & $1.71 \mathrm{E}-30$ & $4.46 \mathrm{E}-26$ & suppressor of variegation 3-9 homolog 2 \\
\hline 6122 & RPL3 & 7.75 & 7.06 & -1.17 & $5.60 \mathrm{E}-11$ & $1.00 \mathrm{E}-08$ & 1 & ribosomal protein L3 \\
\hline 9319 & TRIP13 & 7.71 & 12.67 & 12.03 & $7.80 \mathrm{E}-11$ & $5.35 E-33$ & $1.43 E-29$ & thyroid hormone receptor interactor 13 \\
\hline 195828 & ZNF367 & 7.7 & 12.64 & 10.1 & $8.11 E-11$ & $7.70 E-33$ & $3.50 \mathrm{E}-20$ & zinc finger protein 367 \\
\hline 55635 & DEPDC1 & 7.58 & 11.61 & 10.75 & 2.03E-10 & $2.34 \mathrm{E}-27$ & $3.71 \mathrm{E}-23$ & DEP domain containing 1 \\
\hline 6129 & RPL7 & 7.57 & 6.84 & -1.78 & $2.28 \mathrm{E}-10$ & 4.95E-08 & 1 & ribosomal protein L7 \\
\hline 6194 & RPS6 & 7.5 & 6.97 & -1.71 & $3.86 \mathrm{E}-10$ & $1.90 \mathrm{E}-08$ & 1 & ribosomal protein $\mathrm{S} 6$ \\
\hline 3833 & KIFC1 & 7.49 & 12.53 & 11.27 & $4.21 \mathrm{E}-10$ & $3.28 \mathrm{E}-32$ & $1.14 \mathrm{E}-25$ & kinesin family member $\mathrm{C} 1$ \\
\hline 4173 & MCM4 & 7.48 & 12.5 & 10.21 & 4.54E-10 & 4.67E-32 & $1.10 \mathrm{E}-20$ & minichromosome maintenance complex component 4 \\
\hline 7272 & TTK & 7.45 & 12.41 & 11.37 & $5.79 E-10$ & $1.33 E-31$ & $3.68 \mathrm{E}-26$ & TTK protein kinase \\
\hline 6241 & RRM2 & 7.37 & 11.92 & 9.9 & $1.05 \mathrm{E}-09$ & $5.77 E-29$ & $2.58 \mathrm{E}-19$ & ribonucleotide reductase regulatory subunit $\mathrm{M} 2$ \\
\hline 6188 & RPS3 & 7.35 & 7.32 & -1.36 & $1.16 \mathrm{E}-09$ & 1.49E-09 & 1 & ribosomal protein $\mathrm{S} 3$ \\
\hline 1111 & CHEK1 & 7.35 & 12.93 & 11.23 & $1.21 \mathrm{E}-09$ & $1.96 E-34$ & $1.70 \mathrm{E}-25$ & checkpoint kinase 1 \\
\hline 8458 & TTF2 & 7.31 & 11.22 & 9.76 & $1.65 \mathrm{E}-09$ & $1.95 \mathrm{E}-25$ & $9.68 \mathrm{E}-19$ & transcription termination factor 2 \\
\hline 7112 & TMPO & 7.17 & 12.52 & 11.03 & 4.57E-09 & $3.47 E-32$ & $1.58 \mathrm{E}-24$ & thymopoietin \\
\hline 5347 & PLK1 & 7.16 & 12.07 & 11.13 & $5.00 \mathrm{E}-09$ & $9.04 E-30$ & $5.44 E-25$ & polo like kinase 1 \\
\hline 51545 & ZNF581 & 7.1 & 7.01 & -0.54 & $7.39 \mathrm{E}-09$ & $1.44 \mathrm{E}-08$ & 1 & zinc finger protein 581 \\
\hline 64105 & CENPK & 7.08 & 12.35 & 12.01 & $8.70 \mathrm{E}-09$ & $3.01 E-31$ & $1.97 \mathrm{E}-29$ & centromere protein $\mathrm{K}$ \\
\hline 1938 & EEF2 & 7.02 & 4.16 & -1.13 & $1.37 E-08$ & 0.194 & 1 & eukaryotic translation elongation factor 2 \\
\hline 6128 & RPL6 & 7 & 6.38 & -1.9 & $1.59 \mathrm{E}-08$ & $1.09 \mathrm{E}-06$ & 1 & ribosomal protein $\mathrm{L} 6$ \\
\hline 84722 & PSRC1 & 6.99 & 12.3 & 12.01 & $1.67 \mathrm{E}-08$ & $5.73 E-31$ & $1.85 \mathrm{E}-29$ & proline and serine rich coiled-coil 1 \\
\hline 3148 & HMGB2 & 6.93 & 11.69 & 11.59 & $2.55 \mathrm{E}-08$ & $8.51 E-28$ & $2.91 \mathrm{E}-27$ & high mobility group box 2 \\
\hline 4171 & MCM2 & 6.93 & 12.51 & 10.32 & $2.56 \mathrm{E}-08$ & 4.23E-32 & $3.36 \mathrm{E}-21$ & minichromosome maintenance complex component 2 \\
\hline 6208 & RPS14 & 6.93 & 6.1 & -2.08 & $2.57 E-08$ & 6.33E-06 & 1 & ribosomal protein $\mathrm{S} 14$ \\
\hline 1870 & E2F2 & 6.92 & 12.43 & 10.66 & $2.66 \mathrm{E}-08$ & $1.09 E-31$ & $9.50 \mathrm{E}-23$ & E2F transcription factor 2 \\
\hline 1936 & EEF1D & 6.89 & 3.66 & -2.99 & 3.27E-08 & 1 & 1 & eukaryotic translation elongation factor 1 delta \\
\hline 983 & CDK1 & 6.89 & 12.64 & 11.55 & $3.28 \mathrm{E}-08$ & $7.62 E-33$ & $4.22 \mathrm{E}-27$ & cyclin dependent kinase 1 \\
\hline 4436 & MSH2 & 6.85 & 10.5 & 8.36 & 4.59E-08 & $5.27 E-22$ & $3.89 \mathrm{E}-13$ & muts homolog 2 \\
\hline 6233 & RPS27A & 6.83 & 6.88 & -1 & $5.28 \mathrm{E}-08$ & $3.72 \mathrm{E}-08$ & 1 & ribosomal protein $\mathrm{S} 27 \mathrm{a}$ \\
\hline 3476 & IGBP1 & 6.79 & 5.75 & -1.76 & $6.94 \mathrm{E}-08$ & $5.28 \mathrm{E}-05$ & 1 & immunoglobulin binding protein 1 \\
\hline 3070 & HELLS & 6.77 & 11.84 & 10.28 & $7.98 \mathrm{E}-08$ & $1.52 \mathrm{E}-28$ & $5.26 \mathrm{E}-21$ & helicase, lymphoid specific \\
\hline 4175 & MCM6 & 6.76 & 12.29 & 9.7 & $8.59 \mathrm{E}-08$ & $5.97 E-31$ & $1.90 \mathrm{E}-18$ & minichromosome maintenance complex component 6 \\
\hline 79682 & MLF1IP & 6.76 & 12.59 & 11.36 & $8.62 \mathrm{E}-08$ & $1.49 E-32$ & $4.22 \mathrm{E}-26$ & centromere protein $\mathrm{U}$ \\
\hline 57116 & ZNF695 & 6.74 & 11.36 & 10.26 & $9.82 \mathrm{E}-08$ & $4.01 \mathrm{E}-26$ & $6.60 \mathrm{E}-21$ & zinc finger protein 695 \\
\hline 8914 & TIMELESS & 6.69 & 12.87 & 11.2 & $1.31 \mathrm{E}-07$ & $3.88 \mathrm{E}-34$ & $2.49 \mathrm{E}-25$ & timeless circadian regulator \\
\hline 3066 & HDAC2 & 6.67 & 11.66 & 10.63 & $1.56 \mathrm{E}-07$ & $1.17 E-27$ & $1.37 E-22$ & histone deacetylase 2 \\
\hline 6146 & RPL22 & 6.64 & 5.14 & -0.94 & $1.90 \mathrm{E}-07$ & 0.00165 & 1 & ribosomal protein L22 \\
\hline 332 & BIRC5 & 6.64 & 11.9 & 11.47 & $1.95 \mathrm{E}-07$ & $7.35 E-29$ & $1.09 \mathrm{E}-26$ & baculoviral IAP repeat containing 5 \\
\hline 689 & BTF3 & 6.61 & 6.14 & -0.94 & $2.31 \mathrm{E}-07$ & 4.85E-06 & 1 & basic transcription factor 3 \\
\hline 1017 & CDK2 & 6.61 & 11.82 & 9.8 & 2.33E-07 & $1.95 E-28$ & $6.68 \mathrm{E}-19$ & cyclin dependent kinase 2 \\
\hline 9212 & AURKB & 6.59 & 11.82 & 11.04 & 2.67E-07 & $1.76 \mathrm{E}-28$ & $1.52 \mathrm{E}-24$ & aurora kinase B \\
\hline 4666 & NACA & 6.51 & 6 & -1.09 & 4.49E-07 & $1.23 \mathrm{E}-05$ & 1 & nascent polypeptide associated complex subunit alpha \\
\hline 144455 & E2F7 & 6.44 & 12.28 & 10.22 & $7.26 \mathrm{E}-07$ & $7.31 \mathrm{E}-31$ & $1.00 \mathrm{E}-20$ & E2F transcription factor 7 \\
\hline 5427 & POLE2 & 6.3 & 12.12 & 10.61 & $1.82 \mathrm{E}-06$ & $5.25 E-30$ & $1.70 \mathrm{E}-22$ & DNA polymerase epsilon 2 , accessory subunit \\
\hline 7027 & TFDP1 & 6.29 & 11.38 & 9.63 & $1.93 \mathrm{E}-06$ & 3.17E-26 & $3.76 \mathrm{E}-18$ & transcription factor Dp-1 \\
\hline 1978 & EIF4EBP1 & 6.18 & 10.29 & 9.01 & 3.85E-06 & $4.54 E-21$ & $1.20 \mathrm{E}-15$ & eukaryotic translation initiation factor $4 \mathrm{E}$ binding protein 1 \\
\hline 11130 & ZWINT & 6.17 & 11.49 & 9.44 & 4.26E-06 & 8.97E-27 & $2.33 \mathrm{E}-17$ & ZW10 interacting kinetochore protein \\
\hline 6790 & AURKA & 6.09 & 8.53 & 8.5 & $6.83 \mathrm{E}-06$ & $8.81 \mathrm{E}-14$ & $1.13 \mathrm{E}-13$ & aurora kinase $\mathrm{A}$ \\
\hline 4605 & MYBL2 & 6.03 & 12.5 & 11.39 & $1.00 \mathrm{E}-05$ & 4.27E-32 & $2.74 \mathrm{E}-26$ & MYB proto-oncogene like 2 \\
\hline 55723 & ASF1B & 5.85 & 12.24 & 9.99 & $3.02 \mathrm{E}-05$ & $1.16 E-30$ & $9.75 \mathrm{E}-20$ & anti-silencing function $1 \mathrm{~B}$ histone chaperone \\
\hline 51053 & GMNN & 5.93 & 12.04 & 9.59 & $1.78 \mathrm{E}-05$ & $1.28 \mathrm{E}-29$ & $5.09 \mathrm{E}-18$ & geminin DNA replication inhibitor \\
\hline 29127 & RACGAP1 & 5.81 & 11.57 & 10.19 & 3.81E-05 & $3.48 \mathrm{E}-27$ & $1.33 \mathrm{E}-20$ & Rac GTPase activating protein 1 \\
\hline 6941 & TCF19 & 5.12 & 11.41 & 7.9 & 0.00185 & $2.39 \mathrm{E}-26$ & $1.70 \mathrm{E}-11$ & transcription factor 19 \\
\hline 10376 & TUBA1B & 5.75 & 11.37 & 10.01 & $5.51 \mathrm{E}-05$ & $3.51 E-26$ & $8.59 \mathrm{E}-20$ & tubulin alpha $1 \mathrm{~b}$ \\
\hline 672 & BRCA1 & 5.79 & 11.23 & 8.28 & 4.25E-05 & $1.72 \mathrm{E}-25$ & $7.75 \mathrm{E}-13$ & BRCA1 DNA repair associated \\
\hline 10615 & SPAG5 & 5.76 & 11.01 & 10.11 & 5.14E-05 & $2.15 E-24$ & $2.92 \mathrm{E}-20$ & sperm associated antigen 5 \\
\hline 29893 & PSMC3IP & 4.1 & 10.99 & 8.38 & 0.246 & 2.47E-24 & $3.10 \mathrm{E}-13$ & PSMC3 interacting protein \\
\hline 4599 & MX1 & 3.38 & 10.96 & 16.88 & 1 & $3.70 E-24$ & $3.81 \mathrm{E}-60$ & MX dynamin like GTPase 1 \\
\hline 1869 & E2F1 & 5.36 & 10.76 & 8.94 & 0.000506 & 3.06E-23 & $2.31 \mathrm{E}-15$ & E2F transcription factor 1 \\
\hline 4176 & MCM7 & 4.5 & 10.72 & 9.04 & 0.0408 & $5.23 E-23$ & $9.35 \mathrm{E}-16$ & minichromosome maintenance complex component 7 \\
\hline 5888 & RAD51 & 4.7 & 10.69 & 6.79 & 0.0155 & $7.22 \mathrm{E}-23$ & $6.88 \mathrm{E}-08$ & RAD51 recombinase \\
\hline 6996 & TDG & 5.21 & 10.49 & 9.13 & 0.00112 & $5.74 \mathrm{E}-22$ & 4.30E-16 & thymine DNA glycosylase \\
\hline 2237 & FEN1 & 4.59 & 10.3 & 7.23 & 0.027 & 4.16E-21 & $2.92 \mathrm{E}-09$ & flap structure-specific endonuclease 1 \\
\hline 5708 & PSMD2 & 5.89 & 10.29 & 8.52 & $2.27 \mathrm{E}-05$ & 4.83E-21 & $9.94 \mathrm{E}-14$ & proteasome $26 \mathrm{~S}$ subunit, non-ATPase 2 \\
\hline 3159 & HMGA1 & 5.57 & 10.29 & 8.24 & 0.000152 & $4.98 E-21$ & $1.02 \mathrm{E}-12$ & high mobility group AT-hook 1 \\
\hline 1789 & DNMT3B & 5.1 & 10.01 & 8.86 & 0.0021 & $7.98 \mathrm{E}-20$ & $5.00 \mathrm{E}-15$ & DNA methyltransferase 3 beta \\
\hline 1871 & E2F3 & 5.35 & 9.97 & 8.21 & 0.000536 & $1.19 \mathrm{E}-19$ & $1.37 \mathrm{E}-12$ & E2F transcription factor 3 \\
\hline 84515 & MCM8 & 4.72 & 9.9 & 8.29 & 0.014 & $2.40 \mathrm{E}-19$ & $6.71 \mathrm{E}-13$ & minichromosome maintenance 8 homologous recombination repair factor \\
\hline 6839 & SUV39H1 & 4.34 & 9.8 & 8.76 & 0.0851 & $6.84 \mathrm{E}-19$ & $1.18 \mathrm{E}-14$ & suppressor of variegation 3-9 homolog 1 \\
\hline 9355 & LHX2 & 4.49 & 9.79 & 7.8 & 0.0435 & $7.21 \mathrm{E}-19$ & $3.69 \mathrm{E}-11$ & LIM homeobox 2 \\
\hline 9219 & MTA2 & 5.73 & 9.79 & 8.77 & $6.23 \mathrm{E}-05$ & $7.62 \mathrm{E}-19$ & $1.05 \mathrm{E}-14$ & metastasis associated 1 family member 2 \\
\hline
\end{tabular}


bioRxiv preprint doi: https://doi.org/10.1101/2020.05.12.091256; this version posted May 17, 2020. The copyright holder for this preprint (which was not certified by peer review) is the author/funder, who has granted bioRxiv a license to display the preprint in perpetuity. It is made available under aCC-BY-ND 4.0 International license.

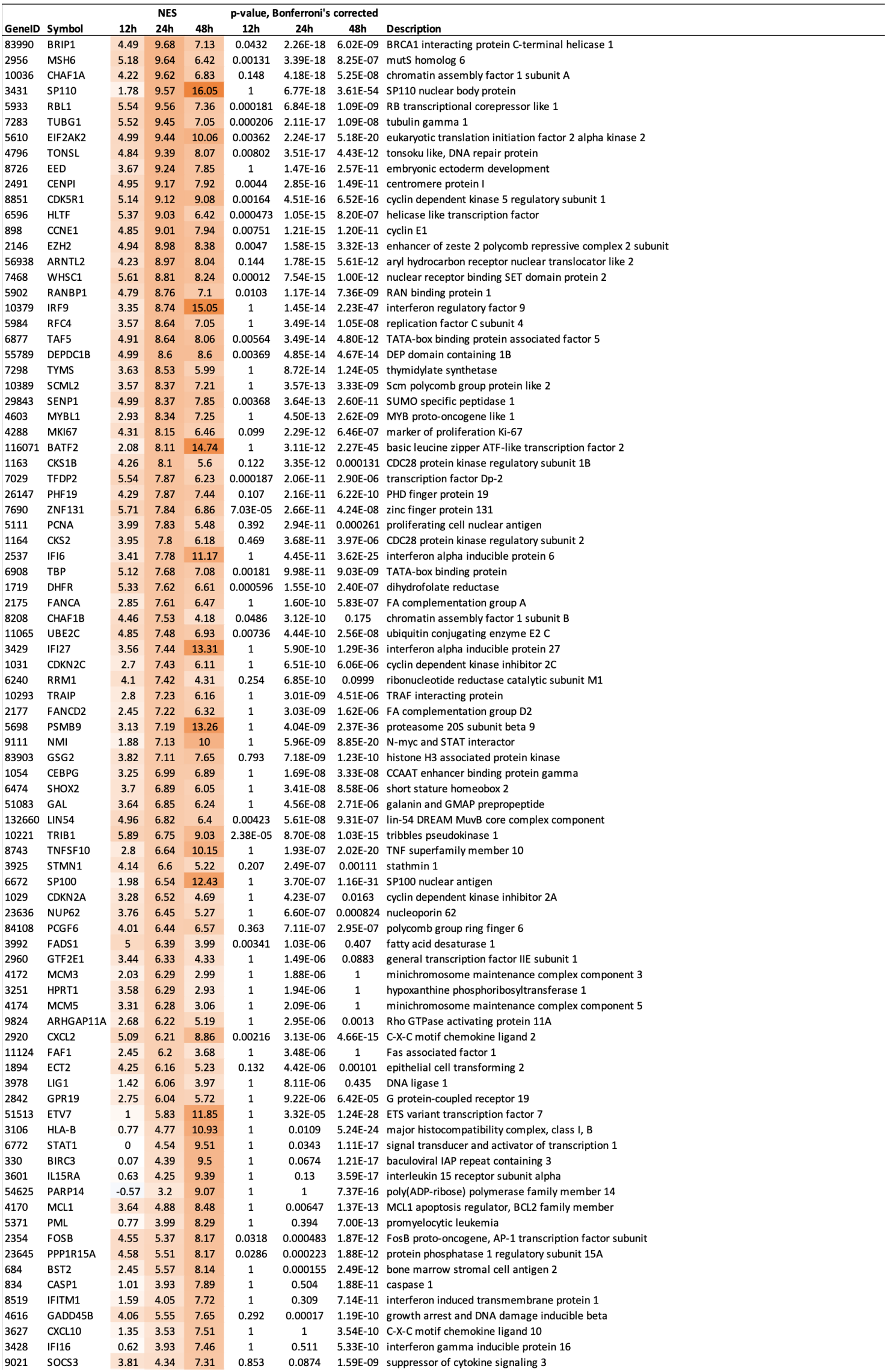


bioRxiv preprint doi: https://doi.org/10.1101/2020.05.12.091256; this version posted May 17, 2020. The copyright holder for this preprint (which was not certified by peer review) is the author/funder, who has granted bioRxiv a license to display the preprint in perpetuity. It is made available under aCC-BY-ND 4.0 International license.

\begin{tabular}{|c|c|c|c|c|c|c|c|c|}
\hline \multirow[b]{2}{*}{ GenelD } & \multirow[b]{2}{*}{ Symbol } & \multicolumn{3}{|c|}{ NES } & \multicolumn{3}{|c|}{ p-value, Bonferroni's corrected } & \multirow{2}{*}{ Description } \\
\hline & & $12 \mathrm{~h}$ & 24h & $48 \mathrm{~h}$ & $12 \mathrm{~h}$ & 24h & $48 \mathrm{~h}$ & \\
\hline 3659 & IRF1 & 0.9 & 3.11 & 7.04 & 1 & 1 & $1.17 \mathrm{E}-08$ & interferon regulatory factor 1 \\
\hline 23764 & MAFF & 3.11 & 3.03 & 7.03 & 1 & 1 & $1.22 \mathrm{E}-08$ & MAF bZIP transcription factor $F$ \\
\hline 1843 & DUSP1 & 4.47 & 3.82 & 6.96 & 0.0483 & 0.806 & $2.02 \mathrm{E}-08$ & dual specificity phosphatase 1 \\
\hline 567 & B2M & 0.6 & 2.78 & 6.94 & 1 & 1 & $2.41 \mathrm{E}-08$ & beta-2-microglobulin \\
\hline 80833 & APOL3 & -0.38 & 3.11 & 6.91 & 1 & 1 & $2.85 \mathrm{E}-08$ & apolipoprotein L3 \\
\hline 282618 & IL29 & 2.66 & 4.75 & 6.91 & 1 & 0.012 & $2.92 \mathrm{E}-08$ & interferon lambda 1 \\
\hline 1839 & HBEGF & 2.68 & 4.12 & 6.9 & 1 & 0.233 & $3.11 \mathrm{E}-08$ & heparin binding EGF like growth factor \\
\hline 3726 & JUNB & 4.46 & 4.77 & 6.9 & 0.0503 & 0.0113 & $3.25 \mathrm{E}-08$ & JunB proto-oncogene, AP-1 transcription factor subunit \\
\hline 7538 & ZFP36 & 4.69 & 3.96 & 6.84 & 0.0164 & 0.447 & $4.70 \mathrm{E}-08$ & ZFP36 ring finger protein \\
\hline 8542 & APOL1 & 0.57 & 3.05 & 6.75 & 1 & 1 & $8.96 \mathrm{E}-08$ & apolipoprotein L1 \\
\hline 4061 & LY6E & 3.27 & 5.23 & 6.65 & 1 & 0.00101 & $1.81 \mathrm{E}-07$ & lymphocyte antigen 6 family member $\mathrm{E}$ \\
\hline 8767 & RIPK2 & 3.32 & 5.85 & 6.64 & 1 & $3.01 \mathrm{E}-05$ & $1.86 \mathrm{E}-07$ & receptor interacting serine/threonine kinase 2 \\
\hline 3717 & JAK2 & 0.65 & 1.87 & 6.54 & 1 & 1 & 3.73E-07 & Janus kinase 2 \\
\hline 93594 & WDR67 & 3.16 & 5.74 & 6.46 & 1 & $5.72 \mathrm{E}-05$ & $6.34 \mathrm{E}-07$ & TBC1 domain family member 31 \\
\hline 4149 & MAX & 0.95 & 2.78 & 6.42 & 1 & 1 & $8.39 \mathrm{E}-07$ & MYC associated factor $\mathrm{X}$ \\
\hline 80149 & ZC3H12A & 1.53 & 2.9 & 6.4 & 1 & 1 & $9.32 \mathrm{E}-07$ & zinc finger $\mathrm{CCCH}$-type containing $12 \mathrm{~A}$ \\
\hline 9510 & ADAMTS1 & 3.27 & 4.12 & 6.3 & 1 & 0.228 & $1.76 \mathrm{E}-06$ & ADAM metallopeptidase with thrombospondin type 1 motif 1 \\
\hline 467 & ATF3 & 3.07 & 3.28 & 6.27 & 1 & 1 & 2.17E-06 & activating transcription factor 3 \\
\hline 4277 & MICB & 2.87 & 5.72 & 6.22 & 1 & $6.30 \mathrm{E}-05$ & $3.08 \mathrm{E}-06$ & MHC class I polypeptide-related sequence B \\
\hline 29126 & CD274 & 0.01 & 3.38 & 6.05 & 1 & 1 & 8.79E-06 & CD274 molecule \\
\hline 1408 & CRY2 & -6.05 & -12.15 & -11.68 & $8.69 \mathrm{E}-06$ & $3.53 \mathrm{E}-30$ & $9.94 \mathrm{E}-28$ & cryptochrome circadian regulator 2 \\
\hline 7508 & XPC & -6.06 & -8.95 & -7.66 & $8.19 \mathrm{E}-06$ & $2.09 \mathrm{E}-15$ & $1.14 \mathrm{E}-10$ & XPC complex subunit, DNA damage recognition and repair factor \\
\hline 2796 & GNRH1 & -6.09 & -6.21 & -3.95 & $6.77 \mathrm{E}-06$ & $3.22 \mathrm{E}-06$ & 0.463 & gonadotropin releasing hormone 1 \\
\hline 7569 & ZNF182 & -6.19 & -5.78 & -2.29 & $3.64 \mathrm{E}-06$ & 4.47E-05 & 1 & zinc finger protein 182 \\
\hline 117608 & ZNF354B & -6.22 & -6.33 & -3.12 & $3.08 \mathrm{E}-06$ & $1.46 \mathrm{E}-06$ & 1 & zinc finger protein $354 \mathrm{~B}$ \\
\hline 10608 & MXD4 & -6.22 & -10.81 & -8.9 & $2.92 \mathrm{E}-06$ & $1.92 \mathrm{E}-23$ & $3.33 \mathrm{E}-15$ & MAX dimerization protein 4 \\
\hline 152098 & ZCWPW2 & -6.33 & -11.48 & -9.5 & $1.45 \mathrm{E}-06$ & $1.04 \mathrm{E}-26$ & $1.23 \mathrm{E}-17$ & zinc finger CW-type and PWWP domain containing 2 \\
\hline 26118 & WSB1 & -6.46 & -5.8 & -3.23 & $6.52 \mathrm{E}-07$ & 4.12E-05 & 1 & WD repeat and SOCS box containing 1 \\
\hline 2550 & GABBR1 & -6.47 & -6.13 & -4 & $5.88 \mathrm{E}-07$ & $5.43 \mathrm{E}-06$ & 0.391 & gamma-aminobutyric acid type B receptor subunit 1 \\
\hline 84163 & GTF2IRD2 & -6.57 & -10.34 & -8.55 & $3.14 \mathrm{E}-07$ & $2.95 \mathrm{E}-21$ & $7.16 \mathrm{E}-14$ & GTF2I repeat domain containing 2 \\
\hline 11030 & RBPMS & -6.8 & -10.64 & -10.7 & $6.32 \mathrm{E}-08$ & $1.22 \mathrm{E}-22$ & $6.46 \mathrm{E}-23$ & RNA binding protein, mRNA processing factor \\
\hline 29800 & ZDHHC1 & -7.21 & -10.58 & -10.03 & 3.39E-09 & $2.17 \mathrm{E}-22$ & $6.51 \mathrm{E}-20$ & zinc finger DHHC-type containing 1 \\
\hline 58487 & CREBZF & -7.26 & -6.76 & -3.87 & $2.35 \mathrm{E}-09$ & $8.36 \mathrm{E}-08$ & 0.669 & CREB/ATF bZIP transcription factor \\
\hline 80778 & ZNF34 & -2.47 & -6.09 & -4.84 & 1 & $6.87 \mathrm{E}-06$ & 0.0078 & zinc finger protein 34 \\
\hline 7626 & ZNF75D & -4.64 & -6.11 & -3.13 & 0.0208 & $6.13 \mathrm{E}-06$ & 1 & zinc finger protein 75D \\
\hline 58191 & CXCL16 & -3.97 & -6.16 & -5.28 & 0.44 & 4.46E-06 & 0.000802 & $\mathrm{C}-\mathrm{X}-\mathrm{C}$ motif chemokine ligand 16 \\
\hline 6604 & SMARCD3 & -3.62 & -6.21 & -5.57 & 1 & 3.31E-06 & 0.000156 & SWI/SNF related, matrix associated, actin dependent regulator of chromatin, subfamily $d$, member 3 \\
\hline 23286 & WWC1 & -3.76 & -6.32 & -6.38 & 1 & $1.62 \mathrm{E}-06$ & $1.10 \mathrm{E}-06$ & WW and $\mathrm{C} 2$ domain containing 1 \\
\hline 9278 & ZBTB22 & -4.48 & -6.62 & -6.81 & 0.0442 & $2.12 \mathrm{E}-07$ & $5.84 \mathrm{E}-08$ & zinc finger and BTB domain containing 22 \\
\hline 9912 & ARHGAP44 & -4.86 & -6.69 & -6.19 & 0.0071 & $1.35 \mathrm{E}-07$ & $3.60 \mathrm{E}-06$ & Rho GTPase activating protein 44 \\
\hline 975 & CD81 & -4.5 & -6.75 & -5.42 & 0.0416 & $8.95 \mathrm{E}-08$ & 0.000359 & CD81 molecule \\
\hline 7113 & TMPRSS2 & -3.19 & -6.81 & -6.73 & 1 & $5.84 \mathrm{E}-08$ & $1.02 \mathrm{E}-07$ & transmembrane serine protease 2 \\
\hline 55625 & ZDHHC7 & -2.46 & -6.93 & -7.07 & 1 & $2.55 \mathrm{E}-08$ & $9.64 \mathrm{E}-09$ & zinc finger DHHC-type palmitoyltransferase 7 \\
\hline 23492 & CBX7 & -5 & -6.94 & -7 & 0.00342 & $2.40 \mathrm{E}-08$ & $1.52 \mathrm{E}-08$ & chromobox 7 \\
\hline 23221 & RHOBTB2 & -3.83 & -6.96 & -6.75 & 0.768 & $2.06 \mathrm{E}-08$ & $9.13 \mathrm{E}-08$ & Rho related BTB domain containing 2 \\
\hline 728656 & DMRTC1B & -4.82 & -6.98 & -5.51 & 0.00857 & $1.80 \mathrm{E}-08$ & 0.000215 & DMRT like family C1B \\
\hline 2122 & MECOM & -5.02 & -6.98 & -7.22 & 0.00313 & $1.74 \mathrm{E}-08$ & $3.26 \mathrm{E}-09$ & MDS1 and EVI1 complex locus \\
\hline 163255 & ZNF540 & -5.07 & -6.99 & -4.62 & 0.00235 & $1.63 \mathrm{E}-08$ & 0.0237 & zinc finger protein 540 \\
\hline 5333 & PLCD1 & -5.21 & -7.03 & -7.04 & 0.00113 & $1.24 \mathrm{E}-08$ & $1.12 \mathrm{E}-08$ & phospholipase C delta 1 \\
\hline 57326 & PBXIP1 & -2.97 & -7.08 & -6.81 & 1 & $8.66 \mathrm{E}-09$ & $6.10 \mathrm{E}-08$ & PBX homeobox interacting protein 1 \\
\hline 81550 & TDRD3 & -4.06 & -7.32 & -6.28 & 0.297 & $1.50 \mathrm{E}-09$ & $2.00 \mathrm{E}-06$ & tudor domain containing 3 \\
\hline 10206 & TRIM13 & -2.34 & -7.44 & -7.36 & 1 & $6.24 \mathrm{E}-10$ & $1.08 \mathrm{E}-09$ & tripartite motif containing 13 \\
\hline 63976 & PRDM16 & -3.38 & -7.57 & -6.82 & 1 & $2.24 \mathrm{E}-10$ & $5.48 \mathrm{E}-08$ & $\mathrm{PR} / \mathrm{SET}$ domain 16 \\
\hline 4784 & NFIX & -4.25 & -7.6 & -7.36 & 0.131 & $1.84 \mathrm{E}-10$ & $1.15 \mathrm{E}-09$ & nuclear factor IX \\
\hline 2788 & GNG7 & -5.96 & -7.74 & -7.26 & 1.57E-05 & $6.01 \mathrm{E}-11$ & $2.28 \mathrm{E}-09$ & G protein subunit gamma 7 \\
\hline 284390 & ZNF763 & -5.99 & -8.49 & -7.99 & $1.26 \mathrm{E}-05$ & $1.24 \mathrm{E}-13$ & $8.33 \mathrm{E}-12$ & zinc finger protein 763 \\
\hline 4306 & NR3C2 & -3.95 & -9.12 & -9.09 & 0.464 & $4.65 E-16$ & $6.10 \mathrm{E}-16$ & nuclear receptor subfamily 3 group C member 2 \\
\hline 5934 & RBL2 & -5.74 & -9.31 & -8.23 & $5.80 \mathrm{E}-05$ & $7.70 \mathrm{E}-17$ & $1.16 \mathrm{E}-12$ & RB transcriptional corepressor like 2 \\
\hline 202018 & TAPT1 & -4.45 & -9.33 & -7.81 & 0.0521 & $6.47 \mathrm{E}-17$ & 3.53E-11 & transmembrane anterior posterior transformation 1 \\
\hline 389524 & GTF2IRD2B & -5.5 & -9.51 & -8.96 & 0.000234 & $1.14 \mathrm{E}-17$ & $1.88 \mathrm{E}-15$ & GTF2I repeat domain containing $2 B$ \\
\hline 54386 & TERF2IP & -3.95 & -9.6 & -8.99 & 0.467 & $4.90 \mathrm{E}-18$ & $1.47 \mathrm{E}-15$ & TERF2 interacting protein \\
\hline 6778 & STAT6 & -5.67 & -9.77 & -7.97 & $8.80 \mathrm{E}-05$ & $8.75 \mathrm{E}-19$ & $9.42 \mathrm{E}-12$ & signal transducer and activator of transcription 6 \\
\hline 7008 & TEF & -5.26 & -10.43 & -9.75 & 0.000857 & $1.13 \mathrm{E}-21$ & $1.09 \mathrm{E}-18$ & TEF transcription factor, PAR bZIP family member \\
\hline 7067 & THRA & -5.28 & -10.82 & -9.83 & 0.00079 & $1.70 \mathrm{E}-23$ & $5.22 \mathrm{E}-19$ & thyroid hormone receptor alpha \\
\hline 80108 & ZFP2 & -5.76 & -11.16 & -10.64 & 4.99E-05 & $3.73 \mathrm{E}-25$ & $1.21 \mathrm{E}-22$ & ZFP2 zinc finger protein \\
\hline 57659 & ZBTB4 & -5.67 & -11.46 & -11.14 & $8.65 \mathrm{E}-05$ & $1.27 \mathrm{E}-26$ & $4.71 \mathrm{E}-25$ & zinc finger and BTB domain containing 4 \\
\hline
\end{tabular}


bioRxiv preprint doi: https://doi.org/10.1101/2020.05.12.091256; this version posted May 17, 2020. The copyright holder for this preprint (which was not certified by peer review) is the author/funder, who has granted bioRxiv a license to display the preprint in perpetuity. It is made available under aCC-BY-ND 4.0 International license.

Supplementary Table 2. FDA-approved drugs and late-stage (phase 2 and 3) investigational compounds in oncology covered by the lung epithelium context-specific MoA database. The table lists the drug/compound name, concentration used to perturb NCI-H1793 lung adenocarcinoma cells, FDA-approval status known primary targets.

\begin{tabular}{|c|c|c|c|}
\hline Compound & Concentration & FDA-approved & Known targets \\
\hline Acalabrutinib & $1.9 \mu \mathrm{M}$ & Yes & BTK \\
\hline Afatinib & $187 \mathrm{nM}$ & Yes & EGFR, ERBB2 \\
\hline Albendazole & $900 \mathrm{nM}$ & Yes & \\
\hline Alectinib & $1 \mu \mathrm{M}$ & Yes & ALK \\
\hline Alexidine & $1 \mu \mathrm{M}$ & Yes & PTPMT1 \\
\hline Alpelisib & $370 \mathrm{nM}$ & Yes & PIK3CA, PIK3CB, PIK3CD, PIK3CG \\
\hline Aminopterin & $1.1 \mu \mathrm{M}$ & Yes & \\
\hline Amsacrine & $2.4 \mu \mathrm{M}$ & Yes & \\
\hline AP26113 & $3.8 \mu \mathrm{M}$ & Yes & ALK, EGFR \\
\hline Apremilast & $450 \mathrm{nM}$ & Yes & \\
\hline Arsenic trioxide & $400 \mathrm{nM}$ & Yes & TXNRD1, PML \\
\hline Axitinib & $144 \mathrm{nM}$ & Yes & FLT1, FLT4, KDR \\
\hline Azacitidine & $4.1 \mu \mathrm{M}$ & Yes & DNMT1, DNMT3A \\
\hline Belinostat & $2.5 \mu \mathrm{M}$ & Yes & pan-HDAC \\
\hline Benzethonium chloride & $5 \mu \mathrm{M}$ & Yes & \\
\hline Bexarotene & $1.6 \mu \mathrm{M}$ & Yes & RXRA, RXRB, RXRG \\
\hline Bleomycin & $276 \mathrm{nM}$ & Yes & LIG1, LIG3 \\
\hline Bortezomib & $68 \mathrm{nM}$ & Yes & Proteasome \\
\hline Bosentan & $833 \mathrm{nM}$ & Yes & EDNRA, EDNRB \\
\hline Bosutinib & $377 \mathrm{nM}$ & Yes & ABL1, SRC \\
\hline Busulfan & $296 \mathrm{nM}$ & Yes & \\
\hline Cabazitaxel & $3 \mathrm{nM}$ & Yes & Tubulin \\
\hline Cabergoline & $0 \mathrm{pM}$ & Yes & \\
\hline Cabozantinib & $1.1 \mu \mathrm{M}$ & Yes & KDR, RET, MET \\
\hline Calcitriol & $5 \mathrm{nM}$ & Yes & \\
\hline Carboplatin & $1 \mu \mathrm{M}$ & Yes & \\
\hline Carfilzomib & $24 \mathrm{nM}$ & Yes & Proteasome \\
\hline Carmustine & $1.6 \mu \mathrm{M}$ & Yes & GSR \\
\hline Ceritinib & $1.4 \mu \mathrm{M}$ & Yes & ALK \\
\hline Cetylpyridinium Chloride & $3 \mu \mathrm{M}$ & Yes & \\
\hline Cinacalcet & $2.4 \mu \mathrm{M}$ & Yes & \\
\hline Cladribine & $718 \mathrm{nM}$ & Yes & \\
\hline Clarithromycin & $1 \mu \mathrm{M}$ & Yes & \\
\hline Clofarabine & $437 \mathrm{nM}$ & Yes & \\
\hline Clofoctol & $4.5 \mu \mathrm{M}$ & Yes & \\
\hline Cobimetinib & $514 \mathrm{nM}$ & Yes & MAP2K1 \\
\hline Copanlisib & $674 \mathrm{nM}$ & Yes & PIK3CA, PIK3CB, PIK3CD, PIK3CG \\
\hline Crizotinib & $193 \mathrm{nM}$ & Yes & MET, ALK \\
\hline Cyclosporine & $1.9 \mu \mathrm{M}$ & Yes & \\
\hline Dabrafenib & $1.6 \mu \mathrm{M}$ & Yes & BRAF, RAF1 \\
\hline Dacomitinib & $53 \mathrm{nM}$ & Yes & EGFR, ERBB2 \\
\hline Dactinomycin & $3 \mathrm{nM}$ & Yes & TOP2A, TOP2B \\
\hline Dasatinib & $345 \mathrm{nM}$ & Yes & SRC, ABL1, BCR, KIT \\
\hline Daunorubicin & $134 \mathrm{nM}$ & Yes & TOP2A, TOP2B \\
\hline Decitabine & $644 \mathrm{nM}$ & Yes & DNMT1, DNMT3A \\
\hline Digoxigenin & $285 \mathrm{nM}$ & Yes & \\
\hline Disulfiram & $14 \mathrm{nM}$ & Yes & ALDH2, DBH \\
\hline Domiphen Bromide & $2.5 \mu \mathrm{M}$ & Yes & \\
\hline Doxorubicin & $239 \mathrm{nM}$ & Yes & TOP2A \\
\hline Dronedarone & $2 \mu \mathrm{M}$ & Yes & \\
\hline Enasidenib & $1.9 \mu \mathrm{M}$ & Yes & IDH2, IDH1 \\
\hline Epigallocatechin & $436 \mathrm{nM}$ & Yes & \\
\hline Epirubicin & $162 \mathrm{nM}$ & Yes & TOP2A, CHD1 \\
\hline Erlotinib & $3.4 \mu \mathrm{M}$ & Yes & EGFR \\
\hline Estramustine & $3.9 \mu \mathrm{M}$ & Yes & \\
\hline Etoposide & $2 \mu \mathrm{M}$ & Yes & TOP2A, ТОР2B \\
\hline Everolimus & $84 \mathrm{nM}$ & Yes & MTOR \\
\hline Exemestane & $1.5 \mu \mathrm{M}$ & Yes & CYP19A1 \\
\hline Fedratinib & $1.5 \mu \mathrm{M}$ & Yes & \\
\hline Fludarabine & $209 \mathrm{nM}$ & Yes & POLA1, RRM1, RRM2 \\
\hline Fulvestrant & $32 \mathrm{nM}$ & Yes & ESR1, ESR2 \\
\hline Gefitinib & $571 \mathrm{nM}$ & Yes & EGFR \\
\hline Gemcitabine & $316 \mathrm{nM}$ & Yes & TYMS \\
\hline Gentian Violet & $45 \mathrm{nM}$ & Yes & \\
\hline Homoharringtonine & $9 \mathrm{nM}$ & Yes & \\
\hline Hydroxychloroquine & $434 \mathrm{nM}$ & Yes & \\
\hline Ibrutinib & $354 \mathrm{nM}$ & Yes & BTK \\
\hline Idarubicin & $24 \mathrm{nM}$ & Yes & TOP2A \\
\hline Idelalisib & $1 \mu \mathrm{M}$ & Yes & PIK3CD, PIK3CA, PIK3CB, PIK3CG \\
\hline Irinotecan & $2.9 \mu \mathrm{M}$ & Yes & TOP1 \\
\hline Ixabepilone & $153 \mathrm{pM}$ & Yes & Tubulin \\
\hline Ixazomib & $43 \mathrm{nM}$ & Yes & PSMB5 \\
\hline Lanatoside & $65 \mathrm{nM}$ & Yes & \\
\hline Lenalidomide & $1.7 \mu \mathrm{M}$ & Yes & TNF, TNFSF11 \\
\hline Lenvatinib & $647 \mathrm{nM}$ & Yes & FLT4, KDR, FLT1 \\
\hline Letrozole & $1.9 \mu \mathrm{M}$ & Yes & CYP19A1 \\
\hline Leucovorin & $2.1 \mu \mathrm{M}$ & Yes & \\
\hline Leuprolide & $76 \mathrm{nM}$ & Yes & GNRHR \\
\hline
\end{tabular}


bioRxiv preprint doi: https://doi.org/10.1101/2020.05.12.091256; this version posted May 17, 2020. The copyright holder for this preprint (which

was not certified by peer review) is the author/funder, who has granted bioRxiv a license to display the preprint in perpetuity. It is made available under aCC-BY-ND 4.0 International license.

\begin{tabular}{|c|c|c|c|}
\hline Compound & Concentration & FDA-approved & Known targets \\
\hline Mechlorethamine & $883 \mathrm{nM}$ & Yes & \\
\hline Megestrol acetate & $49 \mathrm{nM}$ & Yes & \\
\hline Melphalan & $819 \mathrm{nM}$ & Yes & \\
\hline Mercaptopurine & $867 \mathrm{nM}$ & Yes & \\
\hline Miconazole & $2.5 \mu \mathrm{M}$ & Yes & \\
\hline Midostaurin & $700 \mathrm{nM}$ & Yes & FLT3, PRKCA \\
\hline Mitomycin & $4.2 \mu \mathrm{M}$ & Yes & \\
\hline Mitoxantrone & $62 \mathrm{nM}$ & Yes & TOP2A \\
\hline Mycophenolate mofetil & $1.8 \mu \mathrm{M}$ & Yes & IMPDH1, IMPDH2 \\
\hline Nebivolol & $2.7 \mu \mathrm{M}$ & Yes & ADRB1 \\
\hline Neratinib & $230 \mathrm{nM}$ & Yes & ERBB2, EGFR \\
\hline Niclosamide & $500 \mathrm{nM}$ & Yes & \\
\hline Nilotinib & $2.3 \mu \mathrm{M}$ & Yes & ABL1, BCR, PDGFRA, PDGFRB \\
\hline Nintedanib & $139 \mathrm{nM}$ & Yes & FLT4, KDR, PDGFRA, PDGFRB, FGFR1, FGFR2, FLT1 \\
\hline Octreotide & $5 \mathrm{nM}$ & Yes & SSTR2, SSTR3, SSTR5 \\
\hline Osimertinib & $1.7 \mu \mathrm{M}$ & Yes & EGFR \\
\hline Oxaliplatin & $2.7 \mu \mathrm{M}$ & Yes & \\
\hline Palbociclib & $115 \mathrm{nM}$ & Yes & CDK4, CDK6 \\
\hline Panobinostat & $45 \mathrm{nM}$ & Yes & pan-HDAC \\
\hline Penfluridol & $1 \mu \mathrm{M}$ & Yes & \\
\hline Pentostatin & $1 \mu \mathrm{M}$ & Yes & ADA \\
\hline Phenelzine & $1.3 \mu \mathrm{M}$ & Yes & MAOA, МАOB \\
\hline Pimozide & $3 \mu \mathrm{M}$ & Yes & DRD3, DRD2 \\
\hline Pomalidomide & $212 \mathrm{nM}$ & Yes & TNF \\
\hline Ponatinib & $80 \mathrm{nM}$ & Yes & ABL1, BCR, FGFR1, KDR, FLT1, TEK, FLT3, FGFR2, FGFR3, FGFR4 \\
\hline Pralatrexate & $64 \mathrm{nM}$ & Yes & DHFR, TYMS \\
\hline Prednisone & $845 \mathrm{nM}$ & Yes & \\
\hline Procarbazine & $2.3 \mu \mathrm{M}$ & Yes & MAOB, MAOA \\
\hline Propranolol & $1.6 \mu \mathrm{M}$ & Yes & ADRB1 \\
\hline Raloxifene & $9 \mathrm{nM}$ & Yes & ESR1 \\
\hline Romidepsin & $697 \mathrm{nM}$ & Yes & pan-HDAC \\
\hline Rosiglitazone & $2.2 \mu \mathrm{M}$ & Yes & \\
\hline Rucaparib & $3.2 \mu \mathrm{M}$ & Yes & PARP1, PARP2, PARP3 \\
\hline Selinexor & $137 \mathrm{nM}$ & Yes & XPO1 \\
\hline Sorafenib & $4.9 \mu \mathrm{M}$ & Yes & RAF1, BRAF, KDR, PDGFRB \\
\hline Sunitinib & $49 \mathrm{nM}$ & Yes & KIT, PDGFRB, KDR, FLT3 \\
\hline Tacrolimus & $5 \mu \mathrm{M}$ & Yes & \\
\hline Talazoparib & $61 \mathrm{nM}$ & Yes & PARP2 \\
\hline Tamoxifen & $1.1 \mu \mathrm{M}$ & Yes & ESR1 \\
\hline Temsirolimus & $81 \mathrm{nM}$ & Yes & MTOR \\
\hline Teniposide & $212 \mathrm{nM}$ & Yes & TOP2A, ТОР2B \\
\hline Thioguanine & $871 \mathrm{nM}$ & Yes & DNMT1 \\
\hline Thiotepa & $3.6 \mu \mathrm{M}$ & Yes & \\
\hline Tofacitinib & $309 \mathrm{nM}$ & Yes & JAK3, JAK1, STAT3 \\
\hline Topotecan & $162 \mathrm{nM}$ & Yes & TOP1 \\
\hline Toremifene & $1.6 \mu \mathrm{M}$ & Yes & ESR1 \\
\hline Trametinib & $36 \mathrm{nM}$ & Yes & MAP2K1, MAP2K2 \\
\hline Valproic Acid & $2.4 \mu \mathrm{M}$ & Yes & HDAC9 \\
\hline Vemurafenib & $1 \mathrm{nM}$ & Yes & BRAF, RAF1 \\
\hline Verteporfin & $2 \mu \mathrm{M}$ & Yes & \\
\hline Vinblastine & $222 \mathrm{nM}$ & Yes & Tubulin \\
\hline Vinorelbine & $2 \mathrm{nM}$ & Yes & Tubulin \\
\hline Vitamin A & $2.1 \mu \mathrm{M}$ & Yes & \\
\hline Vorinostat & $1.4 \mu \mathrm{M}$ & Yes & pan-HDAC \\
\hline Zinc Pyrithione & $500 \mathrm{nM}$ & Yes & \\
\hline 10-DEBC & $3.9 \mu \mathrm{M}$ & No & AKT1, AKT2, АKT3 \\
\hline 2,3-DCPE & $3.5 \mu \mathrm{M}$ & No & \\
\hline 7-Desacetoxy-6,7-dehydrogedunin & $2 \mu \mathrm{M}$ & No & \\
\hline Abexinostat & $339 \mathrm{nM}$ & No & HDAC1, HDAC8 \\
\hline ABT-751 & $5 \mu \mathrm{M}$ & No & \\
\hline AC-93253 & $190 \mathrm{nM}$ & No & \\
\hline AEE788 & $175 \mathrm{nM}$ & No & ERBB2, KDR, EGFR \\
\hline Akt Inhibitor IV & $255 \mathrm{nM}$ & No & AKT1, AKT2, AKT3 \\
\hline Alisertib & $1.1 \mu \mathrm{M}$ & No & AURKA \\
\hline AMG-208 & $2.7 \mu \mathrm{M}$ & No & MET \\
\hline AMG-900 & $2.5 \mu \mathrm{M}$ & No & AURKC, AURKA, AURKB \\
\hline Amuvatinib & $24 \mathrm{nM}$ & No & KIT, FLT3, MET, RET, PDGFRA, RAD51 \\
\hline AP1903 & $903 \mathrm{nM}$ & No & \\
\hline AT9283 & $936 \mathrm{nM}$ & No & JAK2, JAK3, AURKA, AURKB \\
\hline Atrasentan & $1.7 \mu \mathrm{M}$ & No & EDNRA \\
\hline AVN-944 & $3.7 \mu \mathrm{M}$ & No & \\
\hline AZD1480 & $131 \mathrm{nM}$ & No & JAK2 \\
\hline AZD1775 & $156 \mathrm{nM}$ & No & WEE1 \\
\hline AZD5363 & $1.6 \mu \mathrm{M}$ & No & AKT1, AKT2, АKT3 \\
\hline Bardoxolone Methyl & $145 \mathrm{nM}$ & No & CHUK, IKBKB, NFKB1, NFKB2, NFE2L2, NFKBIA \\
\hline Baricitinib & $415 \mathrm{nM}$ & No & JAK1, JAK2, TYK2 \\
\hline Bax channel blocker & $2.5 \mu \mathrm{M}$ & No & BAX \\
\hline BAY 11-7082 & $5 \mu \mathrm{M}$ & No & \\
\hline Bay 11-7085 & $15 \mathrm{nM}$ & No & IKBKB \\
\hline Bay 11-7821 & $5 \mu \mathrm{M}$ & No & NFKBIA \\
\hline BI 2536 & $250 \mathrm{nM}$ & No & \\
\hline BI-78D3 & $3 \mu \mathrm{M}$ & No & MAPK8 \\
\hline BI-87G3 & $3.5 \mu \mathrm{M}$ & No & MAPK8 \\
\hline Binimetinib & $1 \mu \mathrm{M}$ & No & MAP2K2, MAP2K1 \\
\hline
\end{tabular}


bioRxiv preprint doi: https://doi.org/10.1101/2020.05.12.091256; this version posted May 17, 2020. The copyright holder for this preprint (which

was not certified by peer review) is the author/funder, who has granted bioRxiv a license to display the preprint in perpetuity. It is made available under aCC-BY-ND 4.0 International license.

\begin{tabular}{|c|c|c|c|}
\hline Compound & Concentration & FDA-approved & Known targets \\
\hline Birinapant & $5 \mu \mathrm{M}$ & No & BIRC2, XIAP \\
\hline BMS-833923 & $1.1 \mu \mathrm{M}$ & No & \\
\hline Buparlisib & $300 \mathrm{nM}$ & No & PIK3CA \\
\hline Calcimycin & $340 \mathrm{nM}$ & No & \\
\hline Calmidazolium & $500 \mathrm{nM}$ & No & CALM1 \\
\hline Camptothecin & $4 \mathrm{nM}$ & No & \\
\hline Canertinib & $640 \mathrm{nM}$ & No & EGFR, ERBB2, ERBB4 \\
\hline CC-223 & $931 \mathrm{nM}$ & No & MTOR \\
\hline Cediranib & $222 \mathrm{nM}$ & No & FLT4, KDR, FLT1, KIT, PDGFRA, CSF1R, FLT3, PDGFRB \\
\hline CGP-71683 & $1.3 \mu \mathrm{M}$ & No & NPY5R \\
\hline Chlorothalonil & $3.9 \mu \mathrm{M}$ & No & \\
\hline Combretastatin A4 & $1 \mu \mathrm{M}$ & No & Tubulin \\
\hline CP-100356 & $3.5 \mu \mathrm{M}$ & No & $\mathrm{ABCB} 1$ \\
\hline Crenolanib & $149 \mathrm{nM}$ & No & PDGFRA, PDGFRB, CSF1R, FLT3, KIT \\
\hline Cyproterone & $166 \mathrm{nM}$ & No & \\
\hline Dacinostat & $145 \mathrm{nM}$ & No & HDAC1 \\
\hline Diallyl trisulfide & $880 \mathrm{nM}$ & No & \\
\hline Dinaciclib & $4 \mathrm{nM}$ & No & CDK2, CDK5, CDK1, CDK9 \\
\hline Dovitinib & $591 \mathrm{nM}$ & No & FGFR3, FLT3, KIT, FGFR1, FLT1, PDGFRA, PDGFRB \\
\hline Elesclomol & $54 \mathrm{nM}$ & No & \\
\hline Eniluracil & $4 \mu \mathrm{M}$ & No & \\
\hline ENMD-2076 & $1.5 \mu \mathrm{M}$ & No & \\
\hline Entinostat & $1.7 \mu \mathrm{M}$ & No & HDAC1, HDAC3, HDAC2, HDAC 9 \\
\hline Entospletinib & $1.4 \mu \mathrm{M}$ & No & SYK \\
\hline Enzastaurin & $2.2 \mu \mathrm{M}$ & No & \\
\hline Epothilone B & $251 \mathrm{nM}$ & No & \\
\hline Epothilone D & $1 \mu \mathrm{M}$ & No & \\
\hline EPZ-6438 & $2.4 \mu \mathrm{M}$ & No & EZH2 \\
\hline ER-27319 & $1.5 \mu \mathrm{M}$ & No & SYK \\
\hline Evans blue & $500 \mathrm{nM}$ & No & \\
\hline Ezatiostat & $2.5 \mu \mathrm{M}$ & No & GSTP1 \\
\hline Flavopiridol & $90 \mathrm{nM}$ & No & CDK1, CDK2, CDK4, CDK6 \\
\hline Fluspirilene & $5 \mu \mathrm{M}$ & No & \\
\hline Foretinib & $116 \mathrm{nM}$ & No & MET, KDR \\
\hline Galeterone & $3.6 \mu \mathrm{M}$ & No & \\
\hline Galunisertib & $2.7 \mu \mathrm{M}$ & No & TGFBR1 \\
\hline Gambogic acid & $425 \mathrm{nM}$ & No & \\
\hline GBR-12909 & $2.5 \mu \mathrm{M}$ & No & \\
\hline Gedatolisib & $12 \mathrm{nM}$ & No & PIK3CA, PIK3CG, MTOR \\
\hline Gilteritinib & $2.3 \mu \mathrm{M}$ & No & FLT3 \\
\hline Gitoxigenin diacetate & $70 \mathrm{nM}$ & No & \\
\hline Givinostat & $235 \mathrm{nM}$ & No & pan-HDAC \\
\hline Go6976 & $3 \mu \mathrm{M}$ & No & PRKCA, PRKCB, PRKCG, PRKCD \\
\hline Gossypol & $2.4 \mu \mathrm{M}$ & No & BCL2, BCL2L1 \\
\hline GSK-3 inhibitor IX & $3.5 \mu \mathrm{M}$ & No & GSK3A, GSK3B \\
\hline GSK1059615 & $2 \mu \mathrm{M}$ & No & \\
\hline GSK461364 & $514 \mathrm{nM}$ & No & PLK1 \\
\hline GW-843682X & $1 \mu \mathrm{M}$ & No & PLK1, PLK3 \\
\hline Halofuginone & $1 \mathrm{nM}$ & No & \\
\hline HMN-214 & $515 \mathrm{nM}$ & No & \\
\hline Homidium bromide & $3.3 \mu \mathrm{M}$ & No & \\
\hline IKK-16 & $2.2 \mu \mathrm{M}$ & No & CHUK, IKBKB \\
\hline IMD0354 & $500 \mathrm{nM}$ & No & \\
\hline INCA-6 & $2.3 \mu \mathrm{M}$ & No & NFATC2, NFATC1 \\
\hline INK-128 & $17 \mathrm{nM}$ & No & MTOR \\
\hline Ipatasertib & $459 \mathrm{nM}$ & No & AKT1, АKT3, АKT2 \\
\hline Ispinesib & $543 \mathrm{nM}$ & No & \\
\hline JTC-801 & $2 \mu \mathrm{M}$ & No & \\
\hline Ki8751 & $5 \mu \mathrm{M}$ & No & KDR \\
\hline Kinetin riboside & $4.9 \mu \mathrm{M}$ & No & \\
\hline Leelamine & $2 \mu \mathrm{M}$ & No & \\
\hline Lexibulin & $354 \mathrm{nM}$ & No & \\
\hline Linifanib & $1.4 \mu \mathrm{M}$ & No & FLT1, FLT3, KDR, PDGFRA, PDGFRB \\
\hline Luminespib & $1.1 \mu \mathrm{M}$ & No & HSP90AA1, HSP90AB1 \\
\hline LY-2183240 & $900 \mathrm{nM}$ & No & FAAH \\
\hline LY2228820 & $3 \mu \mathrm{M}$ & No & \\
\hline LY2603618 & $4.6 \mu \mathrm{M}$ & No & \\
\hline LY2835219 & $473 \mathrm{nM}$ & No & \\
\hline LY3023414 & $87 \mathrm{nM}$ & No & MTOR \\
\hline Mangostin & $500 \mathrm{nM}$ & No & \\
\hline Methyl 2,5-dihydroxycinnamate & $864 \mathrm{nM}$ & No & \\
\hline MGCD-265 & $1.1 \mu \mathrm{M}$ & No & FLT1, FLT4, KDR, MET, MST1R, TEK \\
\hline MK-2206 & $756 \mathrm{nM}$ & No & AKT1, АKT2, АKT3 \\
\hline Mocetinostat & $391 \mathrm{nM}$ & No & HDAC1 \\
\hline Momelotinib & $1.6 \mu \mathrm{M}$ & No & JAK1, JAK2 \\
\hline Motesanib & $1.3 \mu \mathrm{M}$ & No & FLT1, KDR, FLT4, PDGFRA, PDGFRB, KIT, RET \\
\hline MST-312 & $4 \mu \mathrm{M}$ & No & TERT \\
\hline Navitoclax & $460 \mathrm{nM}$ & No & BCL2, BCL2L1, BCL2L2 \\
\hline NH125 & $1.5 \mu \mathrm{M}$ & No & EEF2 \\
\hline Niguldipine & $2.7 \mu \mathrm{M}$ & No & ADRA1A \\
\hline NSC-95397 & $2.5 \mu \mathrm{M}$ & No & CDC25A, CDC25C, CDC25B \\
\hline Obatoclax mesylate & $145 \mathrm{nM}$ & No & BCL2 \\
\hline Onalespib & $4.4 \mu \mathrm{M}$ & No & \\
\hline ONO-4059 & $2.2 \mu \mathrm{M}$ & No & BTK \\
\hline
\end{tabular}


bioRxiv preprint doi: https://doi.org/10.1101/2020.05.12.091256; this version posted May 17, 2020. The copyright holder for this preprint (which

was not certified by peer review) is the author/funder, who has granted bioRxiv a license to display the preprint in perpetuity. It is made available under aCC-BY-ND 4.0 International license.

\begin{tabular}{|c|c|c|c|}
\hline Compound & Concentration & FDA-approved & Known targets \\
\hline Oprozomib & $380 \mathrm{nM}$ & No & \\
\hline OTX015 & $3.9 \mu \mathrm{M}$ & No & \\
\hline P276-00 & $444 \mathrm{nM}$ & No & \\
\hline Pacritinib & $573 \mathrm{nM}$ & No & JAK2 \\
\hline Pararosaniline & $355 \mathrm{nM}$ & No & \\
\hline PD-166285 & $75 \mathrm{nM}$ & No & SRC, FGFR1, PDGFRB \\
\hline PD0325901 & $667 \mathrm{nM}$ & No & MAP2K1 \\
\hline Perifosine & $5 \mu \mathrm{M}$ & No & MAPK1, AKT1 \\
\hline Pevonedistat & $2.7 \mu \mathrm{M}$ & No & NAE1 \\
\hline PF-04691502 & $147 \mathrm{nM}$ & No & PIK3CA, PIK3CB, PIK3CD, PIK3CG, MTOR \\
\hline Phenylmercury & $435 \mathrm{nM}$ & No & \\
\hline PI-103 & $110 \mathrm{nM}$ & No & \\
\hline PI3KA Inhibitor IV & $1 \mu \mathrm{M}$ & No & PIK3CA \\
\hline Picoplatin & $2.2 \mu \mathrm{M}$ & No & \\
\hline Pictilisib & $599 \mathrm{nM}$ & No & PIK3CA, PIK3CD \\
\hline Pimasertib & $911 \mathrm{nM}$ & No & MAP2K1, MAP2K2 \\
\hline Pirarubicin & $8 \mathrm{nM}$ & No & \\
\hline Plicamycin & $182 \mathrm{nM}$ & No & \\
\hline Plinabulin & $1.6 \mu \mathrm{M}$ & No & Tubulin \\
\hline Plumbagin & $2 \mu \mathrm{M}$ & No & \\
\hline PP-121 & $350 \mathrm{nM}$ & No & \\
\hline Pracinostat & $420 \mathrm{nM}$ & No & HDAC3, HDAC1, HDAC2, HDAC6 \\
\hline Prenylamine & $2.5 \mu \mathrm{M}$ & No & HET \\
\hline Prinomastat & $468 \mathrm{nM}$ & No & MMP2, MMP9, MMP13, MMP14 \\
\hline Pristimerin & $855 \mathrm{nM}$ & No & MGLL \\
\hline Proscillaridin A & $5 \mathrm{nM}$ & No & \\
\hline Puromycin & $1 \mu \mathrm{M}$ & No & \\
\hline PX-12 & $3 \mu \mathrm{M}$ & No & TXN \\
\hline Pyrvinium & $270 \mathrm{nM}$ & No & \\
\hline Quizartinib & $577 \mathrm{nM}$ & No & \\
\hline RAF265 & $4.9 \mu \mathrm{M}$ & No & \\
\hline Raltitrexed & $11 \mathrm{nM}$ & No & TYMS \\
\hline Refametinib & $2.3 \mu \mathrm{M}$ & No & MAP2K1, MAP2K2 \\
\hline Resminostat & $4.4 \mu \mathrm{M}$ & No & \\
\hline Rigosertib & $90 \mathrm{nM}$ & No & PLK1 \\
\hline Ro 31-8220 Mesylate & $2 \mu \mathrm{M}$ & No & \\
\hline RO4929097 & $1.1 \mu \mathrm{M}$ & No & \\
\hline Rocilinostat & $1.5 \mu \mathrm{M}$ & No & HDAC6 \\
\hline RS-17053 & $2.9 \mu \mathrm{M}$ & No & ADRA1A \\
\hline Ryuvidine & $3.6 \mu \mathrm{M}$ & No & SETD8 \\
\hline Sanguinarine & $1 \mu \mathrm{M}$ & No & \\
\hline Sappanone A dimethyl ether & $2.4 \mu \mathrm{M}$ & No & \\
\hline Saracatinib & $1.1 \mu \mathrm{M}$ & No & SRC, ABL1 \\
\hline Satraplatin & $1.7 \mu \mathrm{M}$ & No & \\
\hline SB-216641 & $4 \mu \mathrm{M}$ & No & HTR1B \\
\hline SB-224289 & $1 \mu \mathrm{M}$ & No & HTR1B \\
\hline SB-743921 & $250 \mathrm{nM}$ & No & \\
\hline SCIO-469 & $4.8 \mu \mathrm{M}$ & No & MAPK14 \\
\hline Serdemetan & $156 \mathrm{nM}$ & No & \\
\hline SGI-1776 & $4 \mu \mathrm{M}$ & No & PIM1, PIM2, PIM3 \\
\hline SNX-2112 & $287 \mathrm{nM}$ & No & HSP90AA1, HSP90AB1 \\
\hline Sphingosine & $3 \mu \mathrm{M}$ & No & \\
\hline SRT1720 & $1.5 \mu \mathrm{M}$ & No & \\
\hline Sulconazole Nitrate & $3.1 \mu \mathrm{M}$ & No & \\
\hline Suloctidil & $1.5 \mu \mathrm{M}$ & No & \\
\hline Tacedinaline & $1.1 \mu \mathrm{M}$ & No & HDAC 1, HDAC2, HDAC 3 \\
\hline TAE684 & $5 \mu \mathrm{M}$ & No & ALK \\
\hline TAK-733 & $268 \mathrm{nM}$ & No & MAP2K1 \\
\hline Talampanel & $1.1 \mu \mathrm{M}$ & No & \\
\hline Tandutinib & $1 \mu \mathrm{M}$ & No & FLT3, KIT, PDGFRB \\
\hline Tariquidar & $1.9 \mu \mathrm{M}$ & No & $\mathrm{ABCB} 1$ \\
\hline Tasquinimod & $520 \mathrm{nM}$ & No & S100A9 \\
\hline Telatinib & $2.4 \mu \mathrm{M}$ & No & FLT4, KIT, KDR \\
\hline Terfenadine & $2.5 \mu \mathrm{M}$ & No & HRH1 \\
\hline Thapsigargin & $15 \mathrm{nM}$ & No & \\
\hline Thymoquinone & $988 \mathrm{nM}$ & No & \\
\hline Tivantinib & $227 \mathrm{nM}$ & No & MET \\
\hline Tivozanib & $176 \mathrm{nM}$ & No & FLT4, KDR, FLT1 \\
\hline Totarol & $4.3 \mu \mathrm{M}$ & No & \\
\hline Trichostatin A & $120 \mathrm{nM}$ & No & \\
\hline Triciribine & $782 \mathrm{nM}$ & No & AKT1, AKT2, AKT3 \\
\hline Tyrothricin & $210 \mathrm{nM}$ & No & \\
\hline UCN-01 & $74 \mathrm{nM}$ & No & AKT1, CHEK1, PDK1, PRKCA, PRKCB \\
\hline Valinomycin & $200 \mathrm{pM}$ & No & \\
\hline Vatalanib & $119 \mathrm{nM}$ & No & KDR, FLT1 \\
\hline Vindesine & $23 \mathrm{nM}$ & No & Tubulin \\
\hline Vistusertib & $108 \mathrm{nM}$ & No & MTOR, PIK3CA, PIK3CB, PIK3CD, PIK3CG \\
\hline Volasertib & $1.3 \mu \mathrm{M}$ & No & PLK1 \\
\hline Voreloxin & $1.2 \mu \mathrm{M}$ & No & \\
\hline Voxtalisib & $504 \mathrm{nM}$ & No & PIK3CG, MTOR, PRKDC \\
\hline YM155 & $16 \mathrm{nM}$ & No & BIRC5 \\
\hline Zibotentan & $1.7 \mu \mathrm{M}$ & No & \\
\hline
\end{tabular}


bioRxiv preprint doi: https://doi.org/10.1101/2020.05.12.091256; this version posted May 17, 2020. The copyright holder for this preprint (which was not certified by peer review) is the author/funder, who has granted bioRxiv a license to display the preprint in perpetuity. It is made available under aCC-BY-ND 4.0 International license.

Supplementary Table 3. FDA-approved drugs and investigational compounds identified by ViroTreat as significantly inverting the SARS-CoV ViroCheckpoint $\left(p<10^{-10}, \mathrm{BC}, 1\right.$-tail aREA test). The drugs/compounds were sorted according to ViroTreat-inferred statistical significance as inverters of SARS-CoV 12h-, 24h- and 48h-ViroCheckpoints. The table lists the drug/compound name, FDA-approval status, concentration used to perturb the NCI-H1793 lung adenocarcinoma cells, ViroTreat-estimated statistical significance—expressed as $-\log _{10}(p$-value $)$-and know primary targets.

\begin{tabular}{|c|c|c|c|c|c|c|}
\hline Compound & FDA-approved & Concentration & 12 & 24 & 48 & Known targets \\
\hline PD0325901 & No & $667 \mathrm{nM}$ & 19.77 & 27.24 & 15.92 & MAP2K1 \\
\hline Palbociclib & Yes & $115 \mathrm{nM}$ & 18.49 & 23.5 & 15.76 & CDK4, CDK6 \\
\hline Resminostat & No & $4.4 \mathrm{uM}$ & 18.43 & 18.86 & 6.31 & HDAC1, HDAC3, HDAC6 \\
\hline TAK-733 & No & $268 \mathrm{nM}$ & 17.61 & 25.3 & 9.02 & MAP2K1 \\
\hline Pimasertib & No & $911 \mathrm{nM}$ & 16.81 & 25.61 & 21.72 & MAP2K1, MAP2K2 \\
\hline Selinexor & Yes & $137 \mathrm{nM}$ & 16.19 & 19.74 & 6.44 & XPO1 \\
\hline Trametinib & Yes & $36 \mathrm{nM}$ & 16.01 & 24.88 & 14.84 & MAP2K1, MAP2K2 \\
\hline PI3KA Inhibitor IV & No & $1 \mathrm{uM}$ & 15.48 & 21.12 & 9.93 & PIK3CA \\
\hline Cobimetinib & Yes & $514 \mathrm{nM}$ & 14.47 & 20.61 & 3.23 & MAP2K1 \\
\hline Niclosamide & Yes & $500 \mathrm{nM}$ & 14.35 & 15.26 & 1.18 & \\
\hline Panobinostat & Yes & $45 \mathrm{nM}$ & 14.33 & 16.71 & 3.8 & pan-HDAC \\
\hline Pictilisib & No & $599 \mathrm{nM}$ & 14.1 & 10.77 & 0 & PIK3CA, PIK3CD \\
\hline Dasatinib & Yes & $345 \mathrm{nM}$ & 14.09 & 13.58 & 0.8 & SRC, ABL1, BCR, KIT \\
\hline CC-223 & No & $931 \mathrm{nM}$ & 13.81 & 7.52 & 0 & MTOR \\
\hline Everolimus & Yes & $84 \mathrm{nM}$ & 13.8 & 8.91 & 0 & MTOR \\
\hline Foretinib & No & $116 \mathrm{nM}$ & 13.15 & 2.41 & 0 & MET, KDR \\
\hline PF-04691502 & No & $147 \mathrm{nM}$ & 12.61 & 13.92 & 8.62 & PIKЗCA, PIKЗСB, PIK3CD, PIK3CG, MTOR \\
\hline $\mathrm{PI}-103$ & No & $110 \mathrm{nM}$ & 12.46 & 17.81 & 7.79 & PIKЗCA, PIKЗСB, PIK3CD, PIK3CG \\
\hline Refametinib & No & $2.3 \mathrm{uM}$ & 12.45 & 19.13 & 11.13 & MAP2K1, MAP2K2 \\
\hline Belinostat & Yes & $2.5 \mathrm{uM}$ & 12.17 & 7.44 & 0 & pan-HDAC \\
\hline Rocilinostat & No & $1.5 \mathrm{uM}$ & 12.14 & 5.36 & 0 & HDAC6 \\
\hline UCN-01 & No & $74 \mathrm{nM}$ & 12.06 & 17.89 & 11.75 & AKT1, CHEK1, PDK1, PRKCA, PRKCB \\
\hline Motesanib & No & $1.3 \mathrm{uM}$ & 11.51 & 8.84 & 0 & FLT1, KDR, FLT4, PDGFRA, PDGFRB, KIT, RET \\
\hline Erlotinib & Yes & $3.4 \mathrm{uM}$ & 11.49 & 9.2 & 1.32 & EGFR \\
\hline LY3023414 & No & $87 \mathrm{nM}$ & 11.43 & 4.18 & 0 & MTOR \\
\hline Thioguanine & Yes & $871 \mathrm{nM}$ & 11.15 & 1.71 & 0 & DNMT1 \\
\hline Carfilzomib & Yes & $24 \mathrm{nM}$ & 10.94 & 19.4 & 5.87 & Proteasome \\
\hline Temsirolimus & Yes & $81 \mathrm{nM}$ & 10.9 & 7.88 & 0 & MTOR \\
\hline Bardoxolone Methyl & No & $145 \mathrm{nM}$ & 10.41 & 17.55 & 8.63 & CHUK, IKBKB, NFKB1, NFKB2, NFE2L2, NFKBIA \\
\hline IMD0354 & No & $500 \mathrm{nM}$ & 10.24 & 2.21 & 0 & IKBKB \\
\hline TAE684 & No & 5 uM & 8.81 & 23.29 & 24.23 & ALK \\
\hline Thapsigargin & No & $15 \mathrm{nM}$ & 8.23 & 21.32 & 19.56 & \\
\hline AP26113 & Yes & $3.8 \mathrm{uM}$ & 5.93 & 19.54 & 18.69 & ALK, EGFR \\
\hline Ki8751 & No & 5 uM & 9.69 & 19.46 & 7.52 & KDR \\
\hline Binimetinib & No & $1 \mathrm{uM}$ & 7.56 & 17.67 & 13.27 & MAP2K2, MAP2K1 \\
\hline Dovitinib & No & $591 \mathrm{nM}$ & 7.98 & 17.39 & 19.49 & FGFR3, FLT3, KIT, FGFR1, FLT1, PDGFRA, PDGFRB \\
\hline LY2835219 & No & $473 \mathrm{nM}$ & 6.4 & 16.84 & 21.95 & CDK4, CDK6 \\
\hline SNX-2112 & No & $287 \mathrm{nM}$ & 9.51 & 16.84 & 9.58 & HSP90AA1, HSP90AB1 \\
\hline ENMD-2076 & No & $1.5 \mathrm{uM}$ & 5.64 & 16.76 & 23.45 & AURKC \\
\hline Luminespib & No & $1.1 \mathrm{uM}$ & 5.95 & 15.45 & 8.74 & HSP9OAA1, HSP90AB1 \\
\hline Osimertinib & Yes & $1.7 \mathrm{uM}$ & 2.63 & 12.32 & 23.74 & EGFR \\
\hline ОтХ015 & No & $3.9 \mathrm{uM}$ & 1.81 & 11.75 & 18.19 & BRD2, BRD3, BRD4 \\
\hline Cyclosporine & Yes & $1.9 \mathrm{uM}$ & 5.34 & 10.36 & 0 & PPP3R2 \\
\hline Ixabepilone & Yes & $153 \mathrm{pM}$ & 0 & 0 & 24.11 & Tubulin \\
\hline Valinomycin & No & $200 \mathrm{pM}$ & 0 & 0 & 22.84 & \\
\hline Leelamine & No & 2 uM & 0 & 0 & 21.84 & \\
\hline Cladribine & Yes & $718 \mathrm{nM}$ & 0 & 0 & 21.13 & POLA1, POLE, POLE2, POLE3, POLE4, RRM1, RRM2, RRM2B \\
\hline MGCD-265 & No & $1.1 \mathrm{uM}$ & 0 & 1.76 & 21.12 & FLT1, FLT4, KDR, MET, MST1R, TEK \\
\hline Vemurafenib & Yes & $1 \mathrm{nM}$ & 0 & 0.09 & 20.66 & BRAF, RAF1 \\
\hline Midostaurin & Yes & $700 \mathrm{nM}$ & 0 & 4.79 & 20.62 & FLT3, PRKCA \\
\hline PP-121 & No & $350 \mathrm{nM}$ & 0 & 0 & 19.52 & PDGFR, HCK, MTOR, VEGFR2, SRC, ABL \\
\hline Gitoxigenin diacetate & No & $70 \mathrm{nM}$ & 0 & 0 & 19.33 & \\
\hline Octreotide & Yes & $5 \mathrm{nM}$ & 0 & 0 & 19.08 & SSTR2, SSTR3, SSTR5 \\
\hline Gambogic acid & No & $425 \mathrm{nM}$ & 0 & 0 & 18.78 & \\
\hline Dactinomycin & Yes & $3 \mathrm{nM}$ & 0 & 0 & 18.52 & \\
\hline Camptothecin & No & $4 \mathrm{nM}$ & 0 & 0 & 18.24 & TOP1 \\
\hline Apremilast & Yes & $450 \mathrm{nM}$ & 0 & 0 & 17.61 & PDE4, TNF \\
\hline 2,3-DCPE & No & $3.5 \mathrm{uM}$ & 0 & 0 & 17.06 & \\
\hline GSK-3 inhibitor IX & No & $3.5 \mathrm{uM}$ & 0 & 0 & 16.66 & GSK3A, GSK3B \\
\hline Halofuginone & No & $1 \mathrm{nM}$ & 0 & 0 & 16.47 & \\
\hline Cediranib & No & $222 \mathrm{nM}$ & 0 & 0 & 16.41 & FLT4, KDR, FLT1, KIT, PDGFRA, CSF1R, FLT3, PDGFRB \\
\hline Alpelisib & Yes & $370 \mathrm{nM}$ & 0 & 0 & 16.32 & PIKЗСА, РІКЗСВ, РІКЗСD, РІКЗСG \\
\hline Cabozantinib & Yes & $1.1 \mathrm{uM}$ & 0 & 0 & 16.26 & KDR, RET, MET \\
\hline Axitinib & Yes & $144 \mathrm{nM}$ & 0 & 0 & 15.65 & FLT1, FLT4, KDR \\
\hline Valproic Acid & Yes & $2.4 \mathrm{uM}$ & 0 & 0 & 15.33 & HDAC9 \\
\hline
\end{tabular}


bioRxiv preprint doi: https://doi.org/10.1101/2020.05.12.091256; this version posted May 17, 2020. The copyright holder for this preprint (which

was not certified by peer review) is the author/funder, who has granted bioRxiv a license to display the preprint in perpetuity. It is made available under aCC-BY-ND 4.0 International license.

\begin{tabular}{|c|c|c|c|c|c|c|}
\hline Compound & FDA-approved & Concentration & 12 & 24 & 48 & Known targets \\
\hline Melphalan & Yes & $819 \mathrm{nM}$ & 0 & 0 & 15.15 & \\
\hline Pacritinib & No & $573 \mathrm{nM}$ & 0 & 0 & 14.96 & JAK2 \\
\hline Leucovorin & Yes & $2.1 \mathrm{uM}$ & 0 & 0 & 14.53 & TYMS \\
\hline Gentian Violet & Yes & $45 \mathrm{nM}$ & 0 & 0 & 14.45 & \\
\hline Lenvatinib & Yes & $647 \mathrm{nM}$ & 0 & 0 & 14.35 & FLT4, KDR, FLT1 \\
\hline Vinorelbine & Yes & $2 \mathrm{nM}$ & 0 & 0 & 14.28 & Tubulin \\
\hline Plumbagin & No & $2 \mathrm{uM}$ & 0 & 0 & 14.12 & \\
\hline Tamoxifen & Yes & $1.1 \mathrm{uM}$ & 0 & 0 & 13.88 & ESR1 \\
\hline Azacitidine & Yes & $4.1 \mathrm{uM}$ & 0 & 0 & 13.86 & DNMT1, DNMT3A \\
\hline Alectinib & Yes & $1 \mathrm{uM}$ & 0 & 0.25 & 13.64 & ALK \\
\hline Oxaliplatin & Yes & $2.7 \mathrm{uM}$ & 0 & 0 & 13.4 & \\
\hline PD-166285 & No & $75 \mathrm{nM}$ & 0 & 0 & 13.11 & SRC, FGFR1, PDGFRB \\
\hline Bosentan & Yes & $833 \mathrm{nM}$ & 0 & 0 & 12.93 & EDNRA, EDNRB \\
\hline Fulvestrant & Yes & $32 \mathrm{nM}$ & 0 & 2.58 & 12.56 & ESR1, ESR2 \\
\hline Raloxifene & Yes & $9 \mathrm{nM}$ & 0 & 0 & 12.55 & ESR1 \\
\hline AEE788 & No & $175 \mathrm{nM}$ & 0 & 0 & 12.4 & ERBB2, KDR, EGFR \\
\hline Terfenadine & No & $2.5 \mathrm{uM}$ & 0 & 0 & 12.39 & HRH1 \\
\hline LY-2183240 & No & $900 \mathrm{nM}$ & 0 & 0 & 12.3 & FAAH \\
\hline NSC-95397 & No & $2.5 \mathrm{uM}$ & 0 & 0 & 11.97 & $\mathrm{CDC} 25 \mathrm{~A}, \mathrm{CDC25C}, \mathrm{CDC25B}$ \\
\hline Toremifene & Yes & $1.6 \mathrm{uM}$ & 0 & 0 & 11.86 & ESR1 \\
\hline Zibotentan & No & $1.7 \mathrm{uM}$ & 0 & 0 & 11.73 & EDN1 \\
\hline P276-00 & No & $444 \mathrm{nM}$ & 0 & 1.13 & 11.53 & CDK1, CDK4, CDK9 \\
\hline Gilteritinib & No & $2.3 \mathrm{uM}$ & 3.26 & 8.61 & 11.17 & FLT3 \\
\hline Mercaptopurine & Yes & $867 \mathrm{nM}$ & 0 & 0 & 10.96 & HPRT1 \\
\hline Momelotinib & No & $1.6 \mathrm{uM}$ & 5.21 & 8.45 & 10.83 & JAK1, JAK2 \\
\hline Benzethonium chloride & Yes & $5 \mathrm{uM}$ & 0 & 0 & 10.8 & CHRNA4, CHRNB2 \\
\hline Lenalidomide & Yes & $1.7 \mathrm{uM}$ & 0 & 0.03 & 10.62 & TNF, TNFSF11 \\
\hline Ponatinib & Yes & $80 \mathrm{nM}$ & 0 & 0 & 10.46 & ABL1, BCR, FGFR1, KDR, FLT1, TEK, FLT3, FGFR2, FGFR3, FGFR4 \\
\hline
\end{tabular}

